\title{
Putative stem cells in the hemolymph and in the intestinal submucosa of the solitary ascidian Styela plicata
}

Juan Jiménez-Merino ${ }^{1,2+}$, Isadora Santos de Abreu ${ }^{3,4+}$, Laurel S. Hiebert ${ }^{1,2}$, Silvana Allodi ${ }^{3,4}$, Stefano Tiozzo ${ }^{5}$, Cintia M. De Barros ${ }^{6^{*}}$ and Federico D. Brown ${ }^{1,2,7^{*}}$

\begin{abstract}
Background: In various ascidian species, circulating stem cells have been documented to be involved in asexual reproduction and whole-body regeneration. Studies of these cell population(s) are mainly restricted to colonial species. Here, we investigate the occurrence of circulating stem cells in the solitary Styela plicata, a member of the Styelidae, a family with at least two independent origins of coloniality.

Results: Using flow cytometry, we characterized a population of circulating putative stem cells (CPSCs) in S. plicata and determined two gates likely enriched with CPSCs based on morphology and aldehyde dehydrogenase (ALDH) activity. We found an ALDH + cell population with low granularity, suggesting a stem-like state. In an attempt to uncover putative CPSCs niches in S. plicata, we performed a histological survey for hemoblast-like cells, followed by immunohistochemistry with stem cell and proliferation markers. The intestinal submucosa (IS) showed high cellular proliferation levels and high frequency of undifferentiated cells and histological and ultrastructural analyses revealed the presence of hemoblast aggregations in the IS suggesting a possible niche. Finally, we document the first ontogenetic appearance of distinct metamorphic circulatory mesenchyme cells, which precedes the emergence of juvenile hemocytes.
\end{abstract}

Conclusions: We find CPSCs in the hemolymph of the solitary ascidian Styela plicata, presumably involved in the regenerative capacity of this species. The presence of proliferating and undifferentiated mesenchymal cells suggests IS as a possible niche.

Keywords: Cell progenitors, Hemocytes, Intestine, Stem cells, Tunicates

\section{Introduction}

Most metazoans possess migratory cells within their bodies, referred to in coelomate animals as coelomocytes and/or hemocytes [1]. The diversity in structure and function of these cells is considerable. However,

\footnotetext{
*Correspondence: cintiabarros@macae.ufrj.br; fdbrown@usp.br †Juan Jiménez-Merino and Isadora Santos de Abreu contributed equally to this work

${ }^{1}$ Departamento de Zoologia, Instituto de Biociências, Universidade de São Paulo, Rua do Matão, Trav. 14, São Paulo, SP 101 05508-090, Brazil

${ }^{6}$ Laboratório Integrado de Morfologia, Núcleo em Ecologia e Desenvolvimento Sócio Ambiental de Macaé, NUPEM, Universidade Federal do Rio de Janeiro, UFRJ, Macae, RJ, Brazil

Full list of author information is available at the end of the article
}

they accomplish similar functions among taxa, namely, coagulation, immunological defense, oxygen transport, and tissue repair $[2,3]$. It is widely accepted that animal hemocyte lineages derive from an evolutionarily conserved cell type, the hematopoietic stem cell (also blood stem cell) $[1,4,5]$. While hematopoietic stem cells are known to give rise to several hemocyte types in many animals [1], there are some animal taxa in which stem cells circulating in the hemolymph can also contribute to the formation of new animal bodies via asexual reproduction. Such is the case in many colonial invertebrates, such as colonial ascidians (Tunicata). In colonial ascidians, which display a modular layout formed by 
clonally related zooids that arise from asexual propagation [6], circulating progenitor cells-referred to as hemoblasts [5]-are known to be involved in wholebody regeneration and budding $[7,8]$.

The origin and function of circulating putative stem cells (CPSCs) have been described in ascidians of the subfamily Botryllinae (suborder: Stolidobranchia). In this group, multipotent cells in the hemolymph are progenitors of somatic tissues [9] and germline [10]. Botryllid CPSCs play a fundamental role in the biogenesis of new zooids [11-13], and in the transmission of germline and somatic cell lineages [12, 14]. In addition, the differentiation potential of hemoblasts has been experimentally proven in colonies surgically reduced to the peripheral tunic with circulating vessels containing hemolymph [15-17]. In these conditions, hemoblasts adhere to vessel walls and give rise to budlets, which mature into functional zooids $[18,19]$. The cellular mechanisms that underlie budding have also been examined in one species in the suborder Phlebobranchia, Perophora viridis [17]. In both $P$. viridis and $B$. schlosseri, populations of self-renewing circulating progenitor cells seem to be involved in regeneration and budding [12, 17]. Whereas Perophora progenitors were proven to be pluripotent [17], circulating Botryllus progenitors are considered multi- or unipotent [11, 20].

P. viridis and B. schlosseri belong to separate suborders, within which coloniality evolved independently from solitary ancestors [21]. In fact, coloniality has originated multiple times within the ascidians $[6,11,21]$. Thus, the function and presence of CPSCs in asexual development have plausibly convergently evolved across the ascidians. It is likely that the origin of the CPSC cell type underlies the emergence of coloniality in some ascidian lineages. However, the function and presence of such CPSCs in solitary species are unclear. Therefore, investigating the ancestral character state of hemoblasts in a solitary species may provide insights into the events giving rise to CPSCs and coloniality.

The characterization of hemocytes in ascidians has historically lacked a uniform nomenclature due to distinct identification protocols or personal biases in selecting the most important characters for identification [5, 16, 22]. In Styelidae, coloniality has evolved at least twice [21] and hemocytes of colonial species in this family have been previously described [23-25]. Therefore, we focus this study on the solitary Styela plicata as an outgroup species to approximate the ancestral character state of hemoblast populations in the styelid ascidians. S. plicata exhibits five main cell types in the hemolymph: granulocytes, lymphocyte-like cells, morula cells, pigment cells, and hemoblasts $[25,26]$ (Table 1). In S. plicata, hemoblasts are presumably involved in regeneration, including neural regeneration, and share similar morphological characteristics to the colonial circulating stem cells, including a uniform round shape, a relatively small size ( $5 \mu \mathrm{m}$ in diameter), a high nuclear/cytoplasmic ratio, and prominent nucleoli [25-30]. Thus, a somatic stem cell role has been proposed for this specific subpopulation of hemocytes.

Here, we report the occurrence of putative circulatory stem cells in the hemolymph of the solitary $S$. plicata by cytological observations and flow cytometry. Circulatory stem cells in the colonial styelid $B$. schlosseri have been shown to undergo dynamic migration patterns between transient niches of zooids and buds [23, 31]; however, studies of stem cell niches in solitary styelids remain scarce. In this study, we used cell morphometric parameters and a stem cell marker (i.e., ALDH) in combination with imaging flow cytometry to confirm the presence of CPSCs in the circulatory system of solitary S. plicata. High ALDH enzymatic activity occurs in progenitor cells of different animals, and has been used to isolate populations of cells enriched with CPSCs (germline and somatic stem cells) in colonial styelid ascidians, including B. schlosseri $[12,15,32]$ and Polyandrocarpa misakiensis [33, 34]. Next, we identified a site that contained hemoblast aggregations suggesting the presence of a putative niche in the intestinal submucosa of S. plicata using light and electron microscopy. Lastly, we externally examined the time and place in development in which motile cell populations emerged. In contrast to the reduced movements observed in embryonically derived mesenchymal

Table 1 Hemocyte types identified in Styela plicata

\begin{tabular}{llll}
\hline Cell type & Diameter $(\boldsymbol{\mu m})$ & Identified content & Possible function \\
\hline Granulocyte & $4.2-5.2$ & Heparin and histamine & Similar to vertebrate basophiles \\
Lymphocyte-like cell & $3.1-4.8$ & Nitric oxide & Signaling in defense mechanisms \\
Hemoblast & 6.1 & None & Regeneration \\
Morula cell & $8.8-16.1$ & Phenoloxidase Barros et al. [25] & Cytotoxicity \\
Pigment cell & $5.1-13.1$ & Nitrogenated compounds & Pigmentation \\
\hline
\end{tabular}


cells of the ascidian larva, motile cells in the hemocoel (i.e., hemocytes) first appeared during metamorphosis concomitantly to the expansion of an extracorporeal vasculature involved in settlement, but before the heart differentiated. These findings are discussed within an evolutionary framework to understand the original roles of CPSCs in solitary and colonial styelids.

\section{Methodology}

\section{Animal collection}

Styela plicata is a cosmopolitan species, abundant in harbors of the Atlantic coastline. Juveniles grow rapidly and can attain its maximum size of $8 \mathrm{~cm}$ in 6 months [35, 36]. In Brazil, this species is found along the southeastern coastline, including the harbors of Rio de Janeiro, São Sebastião, and Santos [35]. The life cycle encompasses a brief (1-2 days) larval period before the animal settles on a definitive substrate. For this study, adult individuals were collected from the Ilhabela Yacht Club, São Sebastião $\left(23^{\circ} 46^{\prime} 20^{\prime \prime} \mathrm{S}, 45^{\circ} 21^{\prime} 20^{\prime \prime} \mathrm{W}\right)$, the Ponte Edgard Perdigão dock, Santos, $\left(23^{\circ} 59^{\prime} 30.60^{\prime \prime}\right.$ S, 46 $18^{\prime} 10.27^{\prime \prime}$ W), and Praia da Urca harbor $\left(22^{\circ} 56^{\prime} 43^{\prime \prime}\right.$ S, $043^{\circ} 09^{\prime} 48^{\prime \prime}$ W), Rio de Janeiro, Brazil according to the guidelines approved by SISBIO/IBAMA (no 14689). Animals were maintained in aerated aquaria containing seawater and following local temperature conditions that ranged between 20 and $24{ }^{\circ} \mathrm{C}$, pH between 8 and 8.5 , and salinity 35 ppt [37].

\section{Hemocyte description}

To harvest hemocytes, five adult S. plicata were cut through the oral siphon and hemolymph was decanted into a $1.5-\mathrm{mL}$ tube half-filled with Botryllus buffer (25$\mathrm{mM}$ HEPES, 10-mM cysteine, 50-mM ethylenediaminetetraacetic acid in seawater, $\mathrm{pH}$ 7.5). The hemocyte suspension was centrifuged at $780 \times g$ for $10 \mathrm{~min}$, and cells were resuspended in 60- $\mu \mathrm{L}$ Botryllus buffer. Drops of this suspension were transferred onto SuperFrost plus slides (Fisher, Waltham, MA, USA), and left to settle for $30 \mathrm{~min}$. To distinguish intracellular compartments, hemocytes were stained with saturated Neutral Red solution $(10 \mathrm{mg} / \mathrm{mL})$ for acid vesicles, or Sudan Black staining for lipids. Neutral Red (Merck, Darmstadt, Germany) saturated solution in filtered sea water (FSW) was added in equal volume to the slides and cells were immediately prepared for observation. For Sudan Black staining, hemocytes were fixed in $70 \%$ ethanol, immersed in a Sudan Black (Sigma Aldrich, St. Louis, USA) saturated solution $(70 \%)$, washed once in ethanol (3 $\mathrm{min})$, and once in distilled water ( $3 \mathrm{~min}$ ). Coverslips were mounted with glycerol and sealed with nail polish.

Five cell types comprise the hemocyte population in $S$. plicata: hemoblasts, lymphocyte-like cells, granulocytes, morula cells and pigment cells $[25,26]$ (Table 1). To classify and measure relative frequencies of cell types, including intermediate states, we defined and described general morphotypes that can be identified with light microscopy. The relative frequency of morphotypes was estimated by counting Neutral Red-stained cells (two replicates for each individual). Relative frequencies were evaluated after counting 10 fields for each glass slide, corresponding to at least 400 cells, from contiguous fields of view of the cell suspension at $63 \times$. We used four adult individuals of similar size (approximately $4 \mathrm{~cm}$ in length) as replicates for our analyses.

\section{Flow cytometry}

Twelve adult animals with a wide range of sizes (1-6.5 cm, 0.6-14 g wet mass), to capture variation between body mass, were selected for analyses. Water ejection was induced through light pressure and wet weight was measured. Hemolymph was extracted from each individual as previously described. Hemocyte concentrations were calculated using a hemocytometer. All samples cell concentrations were above $3 \times 10^{6}$ cells $/ \mathrm{mL}$. We used $50-\mu \mathrm{L}$ hemocyte suspensions at a concentration of approximately $1 \times 10^{6}$ cells $/ \mathrm{mL}$, which were acquired by centrifugation at $790 \times g$ for $10 \mathrm{~min}$ and resuspension in Botryllus buffer.

To further identify CPSC populations in the hemolymph, we used a combined strategy for cell sorting that evaluates light refraction and enzymatic features to separate populations of hemocytes in these individuals. We used the viable stem cell, BODIPY-aminoacetaldehyde (BAAA)-based kit, ALDEFLUOR ${ }^{\mathrm{TM}}$ (STEMCELL Technologies) to test for the presence of undifferentiated cells. ALDEFLUOR $^{\mathrm{TM}}$ has been extensively used to detect hematopoietic stem cells and progenitors in humans and mice $[38,39,40]$. Additionally, ALDH is present both in mammalian stem cells [41] and in the growing asexual buds of a colonial ascidian, Polyandrocarpa misakiensis [33, 34] as well as somatic and germline circulating stem cells in $B$. schlosseri $[12,32]$. Cells were stained in 1-2-mM BAAA solution in Botryllus buffer at $37{ }^{\circ} \mathrm{C}$ for 20 min. $N, N$-diethylaminobenzaldehyde (DEAB), an inhibitor of ALDH, was used at $200 \mathrm{mM}$ in the staining solution to generate negative controls. Cells were washed twice, resuspended in Botryllus buffer and maintained on ice until analysis.

Sample acquisition was performed with an imaging flow cytometer (FlowSight, Amnis-Merck Millipore) from the Central de Aquisição de Imagens e Microscopia of the Instituto de Biociências (CAIMI-IB). Acquisition speed was set to low and photos were captured at the highest resolution. About 20,000 cells were acquired based on area and the aspect ratio, defined as the value of minor 
axis divided by major cell axis on channel 1 . The focused cells were gated using root mean squared gradient (RMS gradient) based on channel 1 . Channels 1, 2, and 6 were used to analyze brightfield, ALDEFLUOR ${ }^{\mathrm{TM}}$-labeling, and side scatter (SS) parameters, respectively, using the IDEAS software (Amnis-Merck Millipore). Cell doublets and debris were excluded from the single cells used in the analyses based on area and aspect ratio features (Additional file 1: Figure S1). ALDH + cells and subpopulations of hemocytes were determined based on channel 2 (green) and channel 6 intensities. No autofluorescence was detected in S. plicata hemocytes (Additional file 1: Figure S1). Data acquisition was performed using the IDEAS package (Amnis, Seattle, USA). To detect significant increases in ALDH + event abundances using the ALDEFLUOR $^{\mathrm{TM}}$ test, we performed Wilcoxon matchedpairs signed rank tests between tests and controls (as defined by the ALDH inhibitor DEAB).

\section{Whole-body histological analyses}

Whole animals were fixed in $4 \%$ paraformaldehyde (PFA) in FSW for $24 \mathrm{~h}$ and then embedded in paraffin. Whole individuals were cut into sagittal sections of $6 \mu \mathrm{m}$ using a Leica RM2255 microtome (Wetzlar, Germany). For observing general tissue morphology and organization, we used hematoxylin and eosin staining following the method of Gurr [42]. Mallory-Cason trichrome and Gomori trichrome stains were applied following Humason's protocol [43].

\section{Histology}

The intestines of five ascidians were dissected and fixed with $4 \%$ PFA in artificial seawater for $24 \mathrm{~h}$. Tissues were dehydrated in increasing concentrations of ethanol $(70 \%$, $80 \%, 90 \%, 100 \%)$ for $30 \mathrm{~min}$ in each concentration. The tissues were then cleared with xylene for $20 \mathrm{~min}$, and embedded in Paraplast (Sigma, St. Louis, MO, EUA). Histological sections of $5 \mu \mathrm{m}$ were obtained on a rotating microtome (American Optical). Tissue sections were dewaxed with xylene and rehydrated in decreasing concentrations of ethanol and water.

\section{PIWI labeling}

Histological sections obtained as described above were incubated with $10-\mathrm{mM}$ citrate buffer (with $0.05 \%$ Tween 20 , pH 6) at $90{ }^{\circ} \mathrm{C}$ for $30 \mathrm{~min}$ for antigen retrieval, and cooled for $20 \mathrm{~min}$ in a $0.1 \%$ Tween 20 (PBT) solution in $1 \times$ phosphate-buffered saline (PBS), followed by a 5 -min wash with PBT. Sections were incubated with rabbit polyclonal primary antibody against PIWI (1:100; Abcam ab5207, Cambridge, UK) in PBT for $48 \mathrm{~h}$ (Additional file 3: Figure S2). Then, the sections were washed in PBS, incubated with anti-rabbit biotin (K0679, DAKO;
1:100) for $1 \mathrm{~h}$, subsequently incubated in Cy3-associated streptavidin (Sigma-S6402; 1:500) for $1 \mathrm{~h}$. After, the sections were washed in PBS, the nuclei were labeled with DAPI for $10 \mathrm{~min}$ and the sections washed and mounted with Fluoromount (Sigma-F4680). We included sections without the primary antibody incubation as negative controls. We found no nonspecific labeling in the controls.

We analyzed 10 randomly selected images from histological sections of two animals $(n=2)$. Percentages of positive nuclei were obtained independently for each intestinal layer, i.e., mucosa, submucosa, and serosa. Percentages were then compared using Student's $t$ test. Results were expressed as the mean \pm standard error, and differences were considered statistically significant at $p<0.05$ (*). The analyses were done using GraphPad Prism version 6.00 (GraphPad Software, Inc.).

\section{pHH3 labeling}

Sections obtained as outlined above were kept in 2-M $\mathrm{HCl}$ at $50{ }^{\circ} \mathrm{C}$ for $30 \mathrm{~min}$, then transferred to 10 - $\mathrm{mM}$ citrate buffer $\mathrm{pH} 6$ at $90{ }^{\circ} \mathrm{C}$ for $30 \mathrm{~min}$, chilled in PBT for $20 \mathrm{~min}$ and incubated in anti pHH3 rabbit polyclonal antibody (Santa Cruz, sc8656-R; 1:50) for 4 days at $4{ }^{\circ} \mathrm{C}$. The final PBS washes, incubation with secondary antibody using the labeled streptavidin-biotin, DAPI staining, and mounting were performed as described above.

Data were collected from eight randomly selected histological sections of the intestines of two animals $(n=2)$. For comparison, immunofluorescence was also performed in histological sections of the epidermis. The percentages of positive nuclei were obtained independently for each intestinal layer, i.e., mucosa, submucosa, and serosa, as well as for epidermis tissue. The percentages were then compared as described above.

\section{Transmission electron microscopy}

Ascidian intestines were dissected and fixed with a 2.5\% glutaraldehyde solution and $0.1-\mathrm{M}$ sodium cacodylate in artificial sea water for $24 \mathrm{~h}$, washed in 0.1-M cacodylate buffer and post fixed in $\mathrm{OsO}_{4}$ for $40 \mathrm{~min}$. The material was then pre-contrasted with $1 \%$ uranyl acetate diluted in artificial sea water for $24 \mathrm{~h}$. The intestines were washed again in 0.1-M cacodylate buffer, dehydrated in increasing concentrations of acetone (30\% to 100\%) and infiltrated in Embed 812 resin (Electron Microscopy Sciences). Ultrathin sections $(70 \mathrm{~nm})$ were obtained with an RMC ultramicrotome, collected on copper grids (300 mesh), contrasted with $2 \%$ uranyl acetate for 20 min and with $1 \%$ lead citrate for $3 \mathrm{~min}$. The sections were observed under a JEOL 1011 transmission electron microscope, operated at $80 \mathrm{kV}$, in the Rudolf Barth Electron Microscopy Platform from Instituto Oswaldo Cruz/FIOCRUZ (Rio de Janeiro). 


\section{Fertilization and rearing in the laboratory}

In vitro fertilization and culture were modified from Swalla [44]. One-two days after collection, sets of 4 mature adults were separated and each specimen was bisected on the sagittal plane. Gonads were separated and removed from both halves with forceps, and minced over a mesh $(250-\mu \mathrm{m}$ pore size) suspended over a beaker with $50 \mathrm{~mL}$ of FSW. The resulting gamete suspension was kept still for $15 \mathrm{~min}$, after which all oocytes settled on the bottom of the beaker. Supernatant containing suspended sperm was decanted into $15-\mathrm{mL}$ tubes for crossfertilization. The remaining oocyte medium was washed via reverse filtration with a $50-\mu \mathrm{m}$ mesh and resuspended in FSW. Sperm from each individual was pooled to crossfertilize each oocyte set. Gametes were mixed for $15 \mathrm{~min}$ before removal of excess sperm. Further washes were performed through resuspension in FSW every $30 \mathrm{~min}$ for the first $2 \mathrm{~h}$ after fertilization, and three more times every hour.

At $12 \mathrm{~h}$ post-fertilization, larvae were left in the dark to settle on glass dishes. At around $48 \mathrm{~h}$ post-fertilization, after tail resorption, young metamorphs were carefully removed from the glass with a tungsten needle and relocated to microscopy slides using a glass pipette. During settlement, adhesive papillae fully differentiated, which allowed the animals to adhere to the slide surface. Development was documented with a stereomicroscope Leica M205 FA and an inverted microscope Leica DMi8.

\section{Results}

Frequency and characterization of hemocyte morphotypes in Styela plicata

We established hemocyte categories based on morphological features. We found eight cell morphotypes that were previously described in S. plicata, as well as in other ascidians [5, 22, 25, 45, 46]: lymphocyte-like cells, hemoblasts, univacuolar refractile granulocytes, amoeboid granulocytes, compartment cells, univacuolar cells, morula cells, and pigment cells (Fig. 1a-x). Roughly $50 \%$ of hemocytes were not easily classified into any of the previous cell types (data not shown). For simplicity, we decided to combine some of the hemocyte categories above into the following five hemocyte morphotypes (Table 2):

1. Small round cells: These represent the smallest cell types (2.8-6 $\mu \mathrm{m}$ in diameter), which represent $1 / 6$ of all cells in the hemolymph $(16.7 \pm 9.3 \%, n=1384)$. Circular cells with a high nucleus/cytoplasm ratio with few or no granules in the cytoplasm.

2. Granular amoeboid cells: Small amoeboid cells (4-8 $\mu \mathrm{m})$ with granular cytoplasm that represent $1 / 10$ of all cell types $(9.9 \pm 5.9 \%, n=1384)$.
3. Fully differentiated granulocytes: Rounded cells with intermediate size $(5-8.6 \mu \mathrm{m})$ that represent nearly $1 / 2$ of all hemocytes $(46.2 \pm 9.9 \%, n=1384)$. These cells contain numerous granular structures in the cytoplasm, which are most likely inside a large refractile vacuole.

4. Vacuolated cells: These cells represent $1 / 3$ of all cells $(31.4 \pm 8.8 \%, n=1384)$, and vary in size $(5-20 \mu \mathrm{m})$. One or more prominent basophilic vacuoles are present in the cytoplasm.

5. Pigment cells: These large cells $(8-13 \mu \mathrm{m})$ are rare $(3.5 \pm 3.9 \%, n=1384)$, and are saturated with cytoplasmic compartments filled with amber pigment.

Overall, granulocytes represented the most common morphotype, followed by vacuolated cells, small round cells, and pigmented cells (Fig. 1y; Table 2). Hemocyte populations exhibited different frequencies between individual adults.

\section{Hemocytes with high aldehyde dehydrogenase activity were found in the hemolymph of Styela plicata}

To analyze hemocytes present in the hemolymph of S. plicata, we used imaging flow cytometry to characterize morphological features such as cell size, complexity (measured through side and forward scatter, respectively), and ALDEFLUOR ${ }^{\mathrm{TM}}$-generated fluorescence (Fig. 2). We first wanted to analyze the interindividual variation among several adult S. plicata specimens. Interestingly, we observed a positive correlation $\left(r^{2}=0.58, p=0.038\right)$ between the size of individuals (measured by mass/weight) and the level of variation in cell complexity of hemocytes in the hemolymph (measured by the standard deviation of the SS of each hemolymph sample) (Fig. 2a). Next, we analyzed CPSCs in the hemolymph by the use of a viable cell-permeable fluorescent aldehyde dehydrogenase (ALDH) substrate, BODIPY aminoacetaldehyde (BAAA) (Fig. 2b-e). Hemocyte scatter plots relating cell complexity (SS) and aldefluor-generated fluorescence (ALDH activity) showed minimal variation across individual samples; this allowed us to consistently use the same gating system (gates 1-6) to include most cells in the scatter plot across the twelve individual samples (Fig. 2b-e). Coordinates of the selected gate polygons (gates 1-6) are provided in Additional file 2: Table S1. Five randomly selected cells for each gate are shown to highlight the variation of cell types we observed by imaging flow cytometry analyses (Fig. 2c). While cells in each gate varied notably in size, shape, and morphology (brightfield, BF), the levels of fluorescence (ALDH enzymatic activity) and cell complexity (SS) assisted us in the assignment of the distinct informative regions (Fig. 2b, c). Gates 1, 2, and 3 showed 

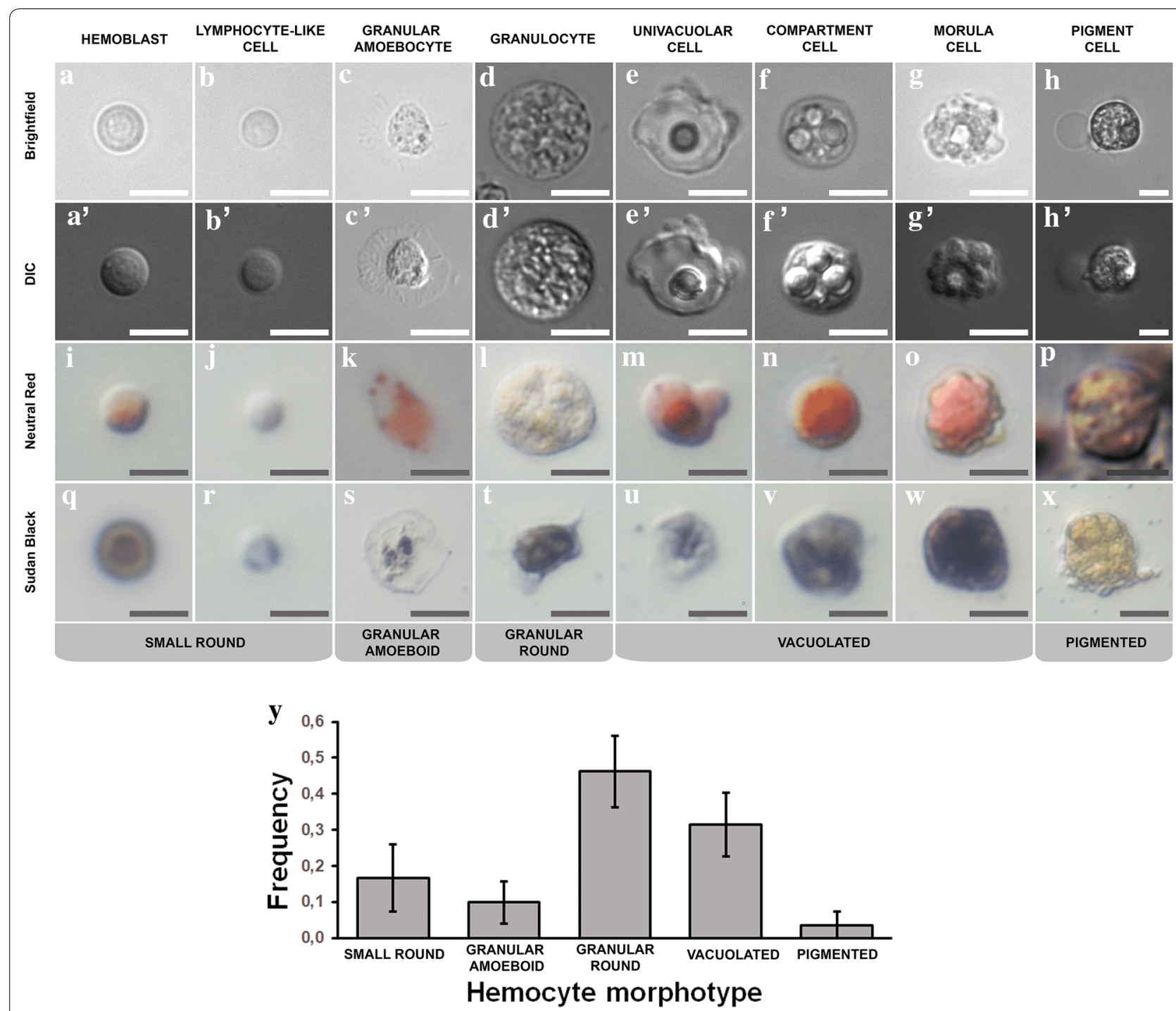

Fig. 1 Styela plicata hemocytes $(\mathbf{a}-\mathbf{x})$ and frequencies $(\mathbf{y}) \cdot \mathbf{a}, \mathbf{a}^{\prime}, \mathbf{i}, \mathbf{q}$ Hemoblast, one of the two types of small round cell with big nucleus (see text for explanation); $\mathbf{b}, \mathbf{b}^{\prime} \mathbf{j}, \mathbf{r}$ lymphocyte-like cell, the other small round cell with big nucleus that is generally smaller than the hemoblast (a, $\mathbf{a}^{\prime}$, $\mathbf{i}, \mathbf{q}) ; \mathbf{c}, \mathbf{c}^{\prime}, \mathbf{k}$, s granular amoebocyte, includes granular ameboid cells with characteristic scattered granules and an irregular membrane; $\mathbf{d}, \mathbf{d}^{\prime}, \mathbf{l}, \mathbf{t}$ univacuolar refractile granulocyte, large granular round cells; $\mathbf{e}, \mathbf{e}^{\prime}, \mathbf{m}$ u univacuolar cell, vacuolated cell type with one conspicuous vacuole; $\mathbf{f}^{\prime} \mathbf{f}^{\prime}, \mathbf{n}, \mathbf{v}$ compartment cell, includes vacuolated cells with $3-5$ vacuoles; $\mathbf{g}, \mathbf{g}^{\prime}, \mathbf{0}, \mathbf{w}$ morula cell, vacuolated cells with numerous vacuoles; $\mathbf{h}, \mathbf{h}^{\prime}, \mathbf{p}, \mathbf{x}$ pigment Cell, includes all pigmented cell types; $\mathbf{y}$ relative frequencies of cell morphotypes show granular round cells as most abundant, whereas pigmented cells are least abundant; small round cells (hemoblast and lymphocyte-like cells) represent about a fifth of all cell types ( $n=4$ individuals, approx. 300 images analyzed). a-h Brightfield, $\mathbf{a}^{\prime}-\mathbf{h}^{\prime}$ DIC, (i-p) Neutral Red, (q-x) Sudan Black. Hemocyte types (shown above) are based on de Leo [22] and de Barros [36, 45], and morphotypes used to calculate frequencies in $(\mathbf{y})$ and in this study are shown below in gray tags. Scale bars $=5 \mu \mathrm{m}$

distinct dispersion patterns and increasing degrees of complexity, as well as BAAA fluorescence (Fig. 2b, c). Gates 4, 5, and 6 indicated high ALDH activity and were considered above the threshold established for positive ALDH + cells, i.e., above relative intensity values of 3100 (Fig. 2b). When comparing all gates, we consistently observed higher numbers of cells in gates 5 and 6 (i.e., the gates corresponding to high ALDH activity): these two gates contained $7.36 \%( \pm 1.96)$ more cells than in the corresponding gates of the DEAB control (Fig. $2 \mathrm{~b}$, d). To test whether the cells in gates 5 and 6 (with high ALDH) were part of a single population of cells, we performed multiple correlation analyses between adult size and gate values of all recorded cell measurements. Only one population of cells (gate 6) showed little or no variation in cell size among individual adults of different size 
Table 2 Cell morphotypes used in this study to classify total hemocyte populations in Styela plicata

\begin{tabular}{|c|c|c|c|c|}
\hline Cell morphotype & Diameter $(\mu \mathrm{m})$ & Percentage (\%) & Possible types & Description \\
\hline Small-round cells & $2.8-6$ & $16.7 \pm 9.3$ & Lymphocyte-like cells, hemoblasts & $\begin{array}{l}\text { Circular cells with a high nucleus/cytoplasm } \\
\text { ratio. Granules scarce or absent }\end{array}$ \\
\hline Granular amoeboid cells & $4-8$ & $9.9 \pm 5.9$ & $\begin{array}{l}\text { Granulocytes and amoeboid cells in dif- } \\
\text { ferentiation }\end{array}$ & $\begin{array}{l}\text { Amoeboid cytoplasm with granular } \\
\text { contents }\end{array}$ \\
\hline Large granulocytes & $5-8.6$ & $46.2 \pm 9.9$ & $\begin{array}{l}\text { Fully differentiated granulocytes, univacu- } \\
\text { olar refractile granulocytes }\end{array}$ & $\begin{array}{l}\text { Rounded contour, numerous granular } \\
\text { structures in cytoplasm, a large refractile } \\
\text { vacuole may be present }\end{array}$ \\
\hline Vacuolated cells & $5-20$ & $31.4 \pm 8.8$ & $\begin{array}{l}\text { Simple univacuolar cells, compartment } \\
\text { cells, morula cells }\end{array}$ & $\begin{array}{l}\text { Cells with one or more prominent baso- } \\
\text { philic vacuoles in the cytoplasm }\end{array}$ \\
\hline Pigmented cell & $8-13$ & $3.5 \pm 3.9$ & Pigment cell & $\begin{array}{l}\text { Large cells, cytoplasm saturated with com- } \\
\text { partments filled with amber pigment }\end{array}$ \\
\hline
\end{tabular}

(Fig. 2e), suggestive of a homogenous population that may contain the CPSCs with hemoblast-like cell characteristics. In contrast, the other informative region with high ALDH + cells (gate 5) showed an increase in the standard deviation of hemocyte area in bigger ascidians (Fig. 2e), suggestive of a more heterogeneous population of cell types within this gate. Therefore, the population of cells at gate 6 meets all morphological criteria of CPSCs: small size, low granularity, and high ALDH activity (most ALDH + cells) suggesting an enrichment of CPSCs at this gate.

We reasoned that if CPSCs contain low cell complexity and present high ALDH activity as expected for other undifferentiated cell types, the ALDEFLUOR ${ }^{\mathrm{TM}}$ assays would show relatively high numbers of cells in gates that show low SS and high ALDH (i.e., gates 5 and 6), and at the same time show relatively low numbers of cells in gates with low SS and low ALDH (i.e., gates 1 and 2). As predicted, when we compared the scatterplot of the ALDEFLUOR $^{\mathrm{TM}}$ assay showing ALDH + cells (Fig. 2b right) to the scatterplot of the basal background fluorescence control showing BAAA treated cells together with the ALDH inhibitor DEAB (Fig. 2b left), we observed a higher number of cells in gates 5 and 6 (i.e., low SS and high $\mathrm{ALDH}$ ) in the ALDEFLUOR ${ }^{\mathrm{TM}}$-treated sample than in the DEAB control (Fig. 2b and d), whereas cells in gates 1 and 2 (i.e., low SS and low ALDH) were significantly reduced in the $A_{L D E F L U O R}{ }^{\mathrm{TM}}$-treated sample than in the DEAB control (Fig. 2b and d). We interpret that many of the low complexity cells located in gates 1 and 2 of the ALDH inhibitor control (Fig. 2b left), correspond to the low complexity cells and high ALDH + cells that become localized in gates 5 and 6 of the ALDEFLUOR ${ }^{\mathrm{TM}}$ assay (Fig. 2b right). Altogether, these data show that circulatory cells with low complexity and high ALDH activity are present in the $S$. plicata hemolymph, which provides evidence for the occurrence of CPSCs in the hemolymph of S. plicata.
The intestine exhibits undifferentiated hemocyte clusters in the subepithelial region

In the intestine of Styela plicata, it is possible to identify three clearly distinct histological regions (Fig. 3). First, the most internal epithelium surrounding the lumen was constituted by a monolayer of columnar cells and a thin basement membrane, and is referred to here as the mucosa (Fig. 3a, c). Second, a middle region with connective tissue and glands, as well as compartmentalized cells (Fig. 3a, b, e-g) is hereinafter referred to as the submucosa. And third, an external region constituted by connective tissue and a simple cubic epithelium (Fig. 3a, b, d) that rests on the coelomic side and shares a common space with other organs through a series of epitheliumbound protrusions or thin layers of muscles is referred to here as the serosa layer (Fig. 3b).

In the submucosa, we identified clusters of hemocytes that appeared to be hemoblasts (Fig. 3). These clusters showed positive expression of the mitotic marker phosphorylated histone 3 ( $\mathrm{pHH} 3$ ) and the undifferentiation marker PIWI by immunofluorescence analyses (Fig. 4a). $\mathrm{pHH} 3+$ cells were observed in putative hemoblast clusters in proximity to glandular structures in the submucosa (Fig. 4b-d, h), but no positive cells were observed in the mucosa or the serosa (Fig. 4h). Although pHH3 + cells varied in frequency across intestinal regions and individuals, we observed at least twice as many proliferating cells in the submucosa (approx. 5.9\% $\pm 1.9 n=8$ ) when compared to proliferating cells of the epidermis (approx. $2.3 \% \pm 0.98 \mathrm{n}=3$ ) (Fig. 4h). In addition we found a high incidence of PIWI expression (approx. 17.24\% \pm 5.9 $n=8$ ) in scattered cells of the submucosa (Fig. $4 \mathrm{~d}-\mathrm{f}$, i), but no expression in the mucosa or the serosa. PIWI was unevenly expressed in the cytoplasm of distinct cell types, including putative hemoblasts and granular cell types (Fig. $4 \mathrm{e}-\mathrm{g}$ ).

Ultrastructural observations in the mesenchyme of the submucosa revealed cell types with undifferentiated 


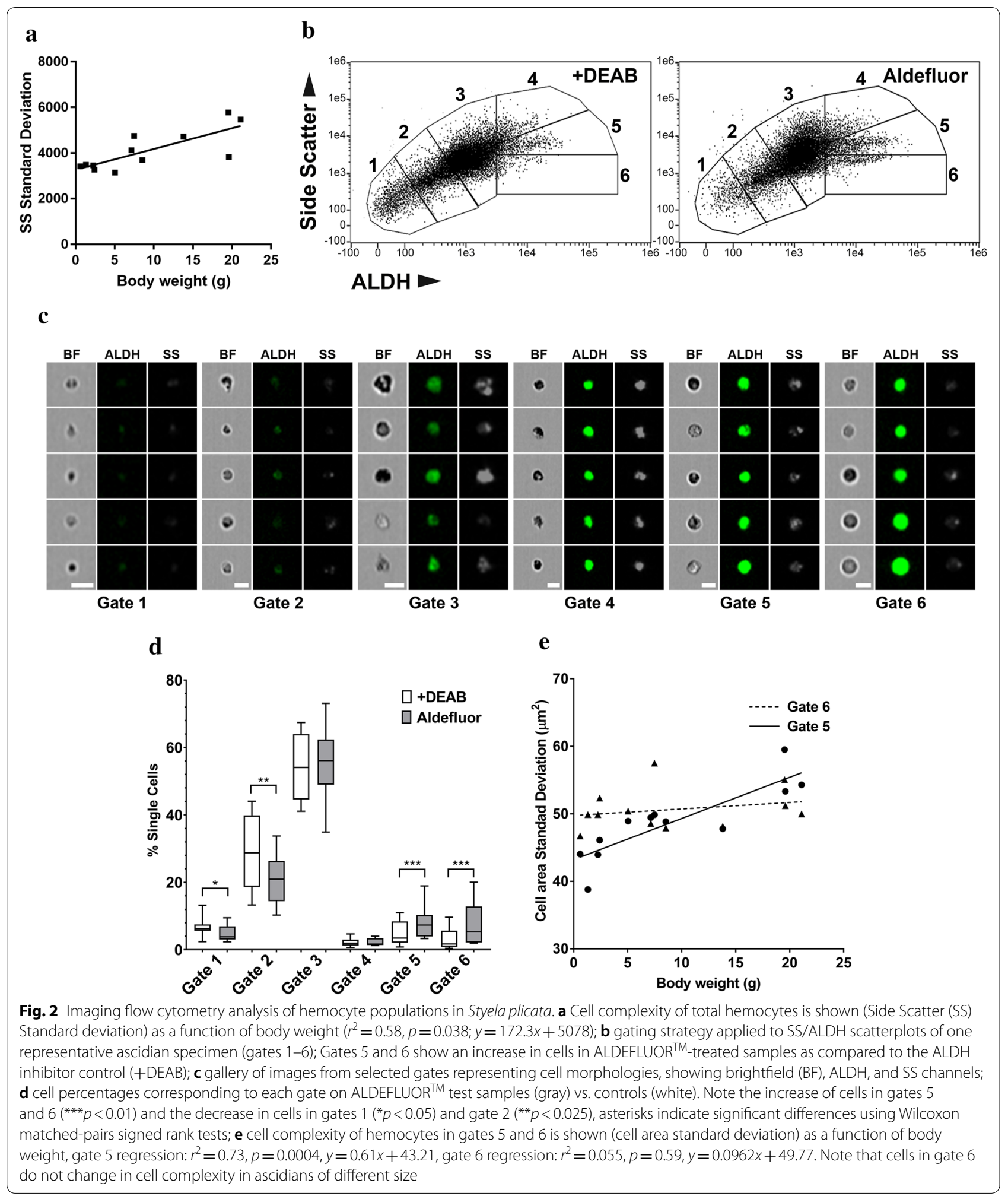




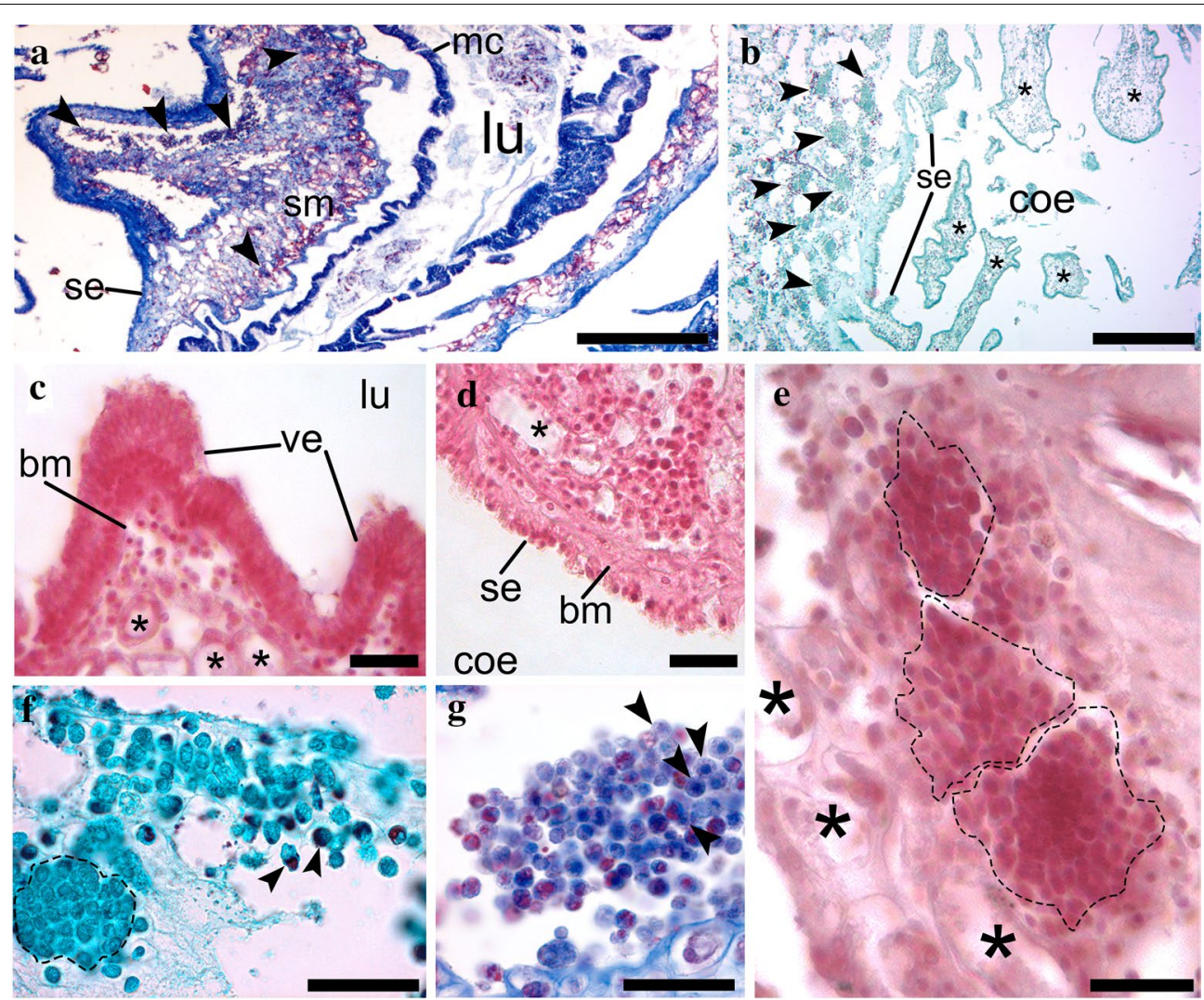

Fig. 3 The cellular structure of Styela plicata intestine, with putative hemoblast clusters found in the submucosa. a Sagittal section of Styela plicata intestine showing its layers, clustered hemoblasts are indicated (arrowheads). b The interface of the serosa with the body cavity (coelom). Hemoblast clusters are indicated with arrowheads. Serosa projections are labeled. Asterisks mark projections of the serosa to the coelom. Note that the connective tissue contains hemoblast clusters. $\mathbf{c}$ Section of the mucosa, showing villi. Glandular structures can be seen beneath the epithelium (asterisks). $\mathbf{d}$ Section of the serosa. The asterisk marks a glandular structure. e Section of the submucosa. Hemoblast clusters are delineated (dashed line). Asterisks highlight glandular structures. $\mathbf{f}$ Detail of niches (delineated with dashed line) located at the outer submucosa. Arrowheads point to free cells with conspicuous granules. $\mathbf{g}$ Niche within the submucosa. Arrowheads point to characteristic hemoblasts. Staining techniques applied: Mallory-Cason trichrome $(\mathbf{a}, \mathbf{g})$, Hematoxylin and Eosin (c-e), Gomori trichrome (b, f). (mc) mucosa, (lu) lumen of the intestine, (bm) basement membrane, (ve) villus extension, (coe) coelom. Scale bars $=5 \mathrm{~mm}$ in $\mathbf{a} ; 2 \mathrm{~mm}$ in $\mathbf{b} ; 50 \mu \mathrm{m}$ in $\mathbf{c}-\mathbf{g}$

morphology: a mainly euchromatic nucleus that occupied most of the cytoplasmic space with none or few small electron-dense granules (Fig. 5). Although several cells in the submucosa showed an undifferentiated morphology (Fig. 5a), we also observed cells that showed features of differentiation including more condensed nuclear chromatin, a smaller nucleus in relation to the cytoplasmic volume, a more irregular plasma membrane, and a higher amount of larger dense vesicles or vacuoles in the cytoplasm (Fig. 5a, b). Cells with undifferentiated morphology were generally observed as clusters and were often found to be associated with glandular cell types (Fig. 5b). In Fig. 5b, part of a gland cell in the submucosa is shown beside a small cell with a big nucleus and thin cytoplasm, but most importantly with a euchromatic nucleus and nucleoli, which are the characteristic features of hemoblast cells. Submucosa cell aggregates also contained cells that showed early and late features of differentiation within the same aggregates. Some of these cells were glandular (Fig. 5b), or presented irregular plasma membranes and lower nuclear/cytoplasm ratios (features of differentiation), and other larger cells showed distinct cytoplasmic granules of differentiated granulocytes (Fig. 5c). Cells in the mucosa showed a typical columnar disposition, with electron-dense granules mainly concentrated on the apical side of each epithelial cell (Fig. 5d). In contrast, cells in the serosa epithelium presented a more cuboidal shape (Fig. 5e).

\section{Styela plicata circulating cells are first apparent during metamorphosis}

The first sign of freely moving cells during development of S. plicata occurred during metamorphosis. As the tadpole larval tail began to resorb during the first phase of 

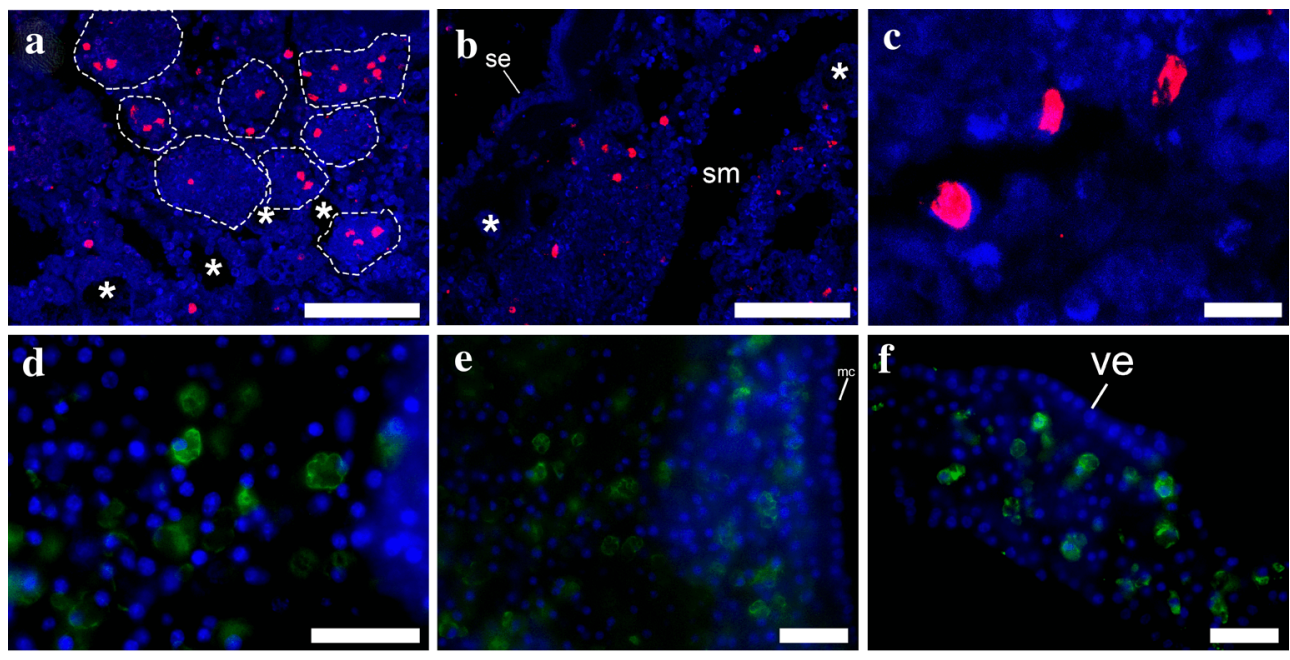

$\mathbf{g}$
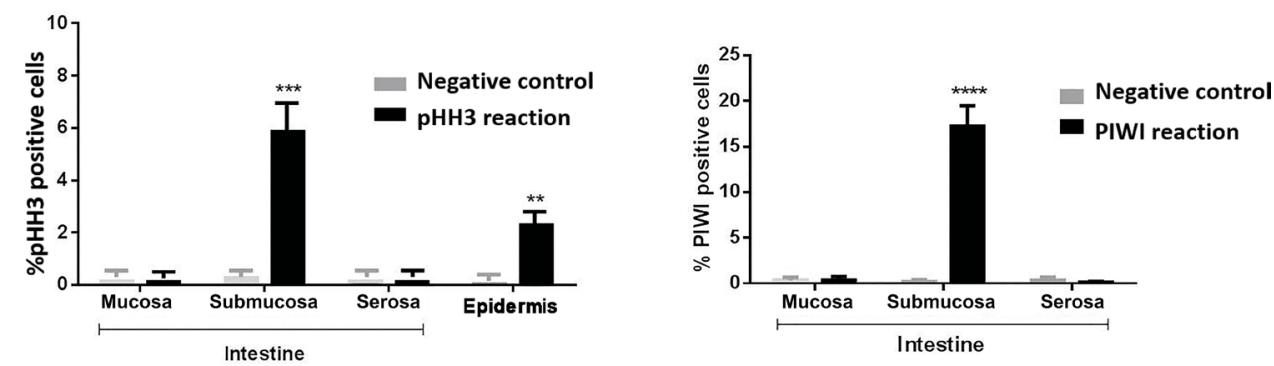

h

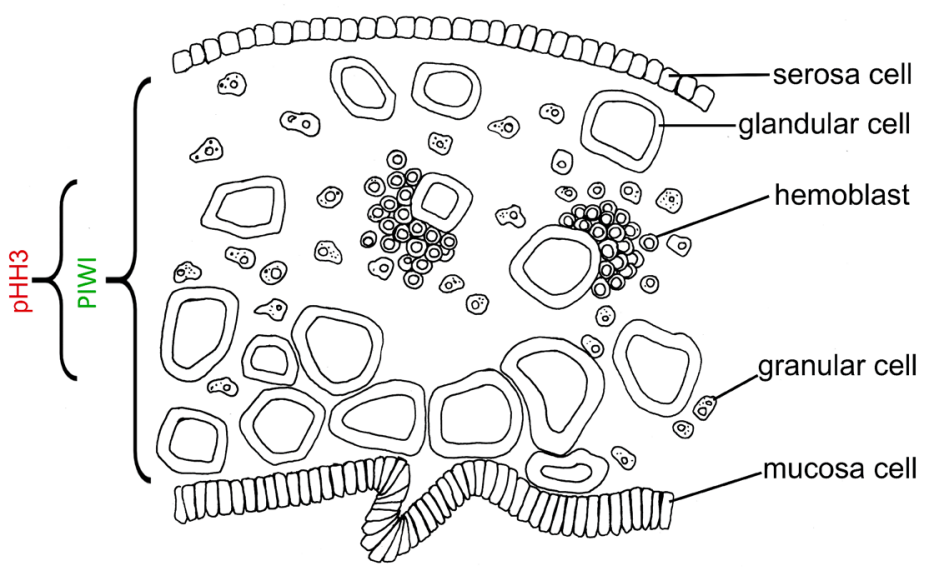

Fig. 4 The intestine of Styela plicata presents PIWI + cells and pHH3 + cells. a-c Phosphohistone (pHH3) immunofluorescence shows antibody reaction in the region of the intestinal epithelia in Styela plicata. All cell nuclei were stained with DAPI (blue). a Wide view of the submucosa region, showing hemoblast aggregations (delineated by dotted lines), glandular structures are highlighted with asterisks. Labeled cells are pseudocolored red. $\mathbf{b}$ Wide view of the intestine subepithelial region below the serosa. Glandular structures are highlighted with asterisks. c Detail of labeled cells with $\mathrm{pHH} 3$ antibody in the submucosa. $\mathbf{d}$-f Immunofluorescence showing antibody reaction with PIWI in the subepithelial region of S. plicata intestine. All cell nuclei were stained with the nucleus marker DAPI (blue) (d) Detail of the submucosa, labeled cells are pseudocolored green. $\mathbf{e}$ Detail of the subepithelial region. $\mathbf{f}$ Intestinal villi showing PIWI + cells at the subepithelial region. $\mathbf{g}$ Cell counts of pHH3 + cells in different regions of the intestine and the epidermis as an external control tissue (left) and PIWI (right) immunofluorescence in the intestine. Epidermis tissue was used for the control group. $\mathbf{h}$ Distribution of the serosa, submucosa, and mucosa cell types in a transverse section of the S. plicata gut showing the range of distribution of pHH3 (red) and PIWI (green) positive cells. $\left(^{*} p<0.05\right)$. (se) serosa, (sm) submucosa, $(\mathrm{m})$ mitochondria, (n) nucleolus. Scale bars $=100 \mu \mathrm{m}$ in $\mathbf{a}, \mathbf{b}$; $20 \mu \mathrm{m}$ in $\mathbf{c}-\mathbf{f}$ 

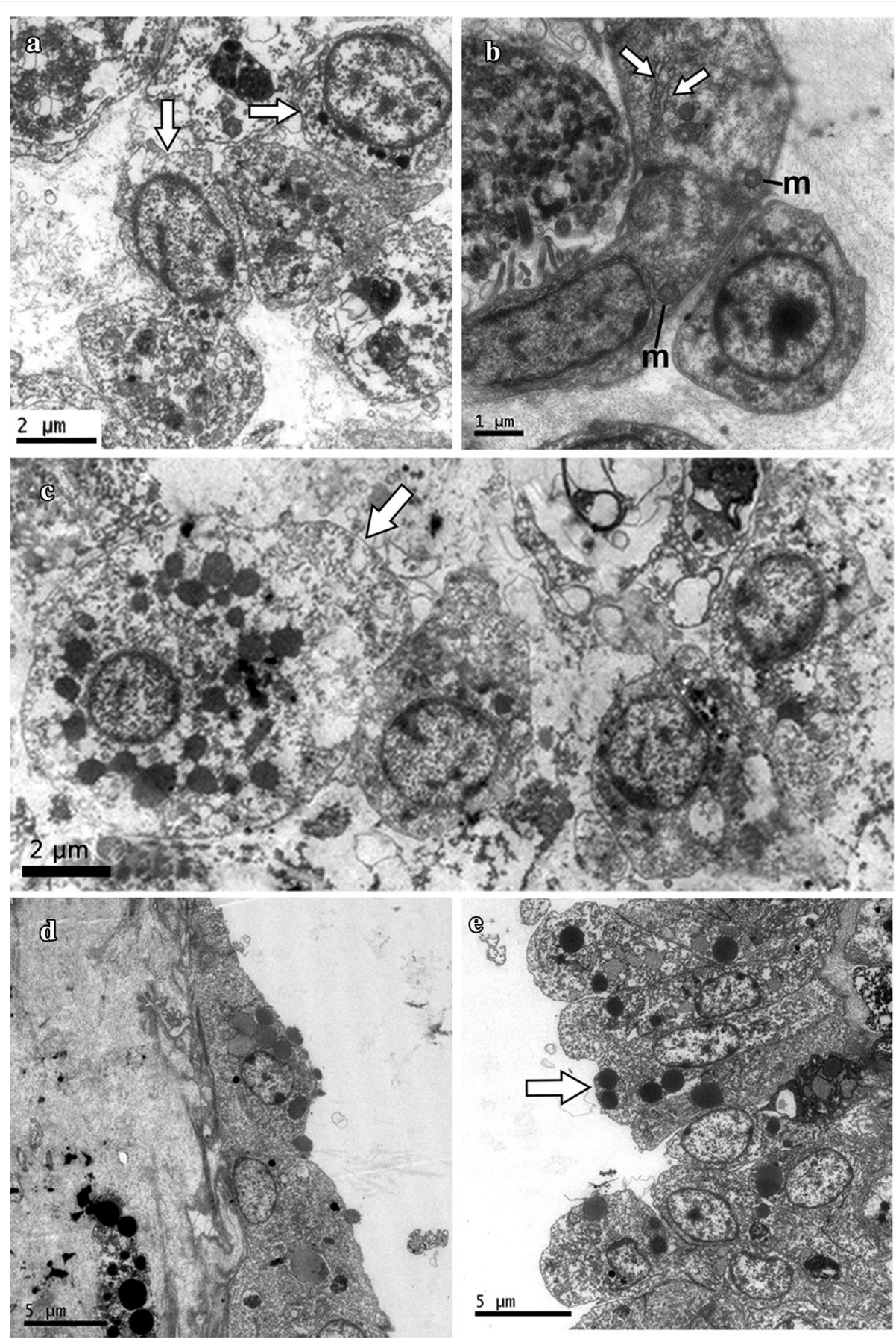

Fig. 5 Ultrastructure of putative hemoblasts and other cell types in the Styela plicata intestinal submucosa. a Cell clusters in the submucosa include undifferentiated cells or putative hemoblasts, as well as other cell types in different stages of maturation. The two lateral cells (arrows) show features of undifferentiation or early stages of differentiation, including a euchromatic nuclei, and small cytoplasmic dense granules; whereas the cell in the center presents features of late differentiation, including larger dense vesicles in the cytoplasm and an irregular plasma membrane. $\mathbf{b}$ An elongated intestinal glandular cell type with endoplasmic reticulum (ER, white arrows) and mitochondria ( $m$ ) is shown next to a putative hemoblast with a large nucleus and distinct nucleolus. c Cells at different stages of maturation in the submucosa; one granulocyte is shown (arrow) next to three smaller cells with irregular plasma membranes. $\mathbf{d}$ Mucosa shows a pseudostratified columnar arrangement and the cells display electron-dense granules on the apical side (black arrow). e Serosa cells show a cuboidal or squamous shape 
metamorphosis, notochordal cells contracted and posterior muscle cells in the tail lost adhesion and underwent morphogenetic changes. At this stage, we observed large actively moving round brown cells, here referred to as globular mesenchyme cells (mc), which migrated actively towards the tadpole head (Fig. 6). Completion of larval tail resorption and exclusion of the larval tunic occurred at about $8 \mathrm{~h}$ after tail resorption began. At this time, the mesenchyme cells that had initiated migration from the posteriormost structures of the tail were now localized on the anterior part of the former larval head and surrounded the rudiment of the alimentary canal (Fig. 6a, b).

After $8 \mathrm{~h}$ post tail resorption, a second phase of metamorphosis began, in which the tunic expanded on the substrate and the juvenile differentiated. At this time, amoeboid cells were observed crawling into the larval tunic in exclusion, and became more active as the juvenile tunic expanded (Fig. 6a, b, f). At this stage, four

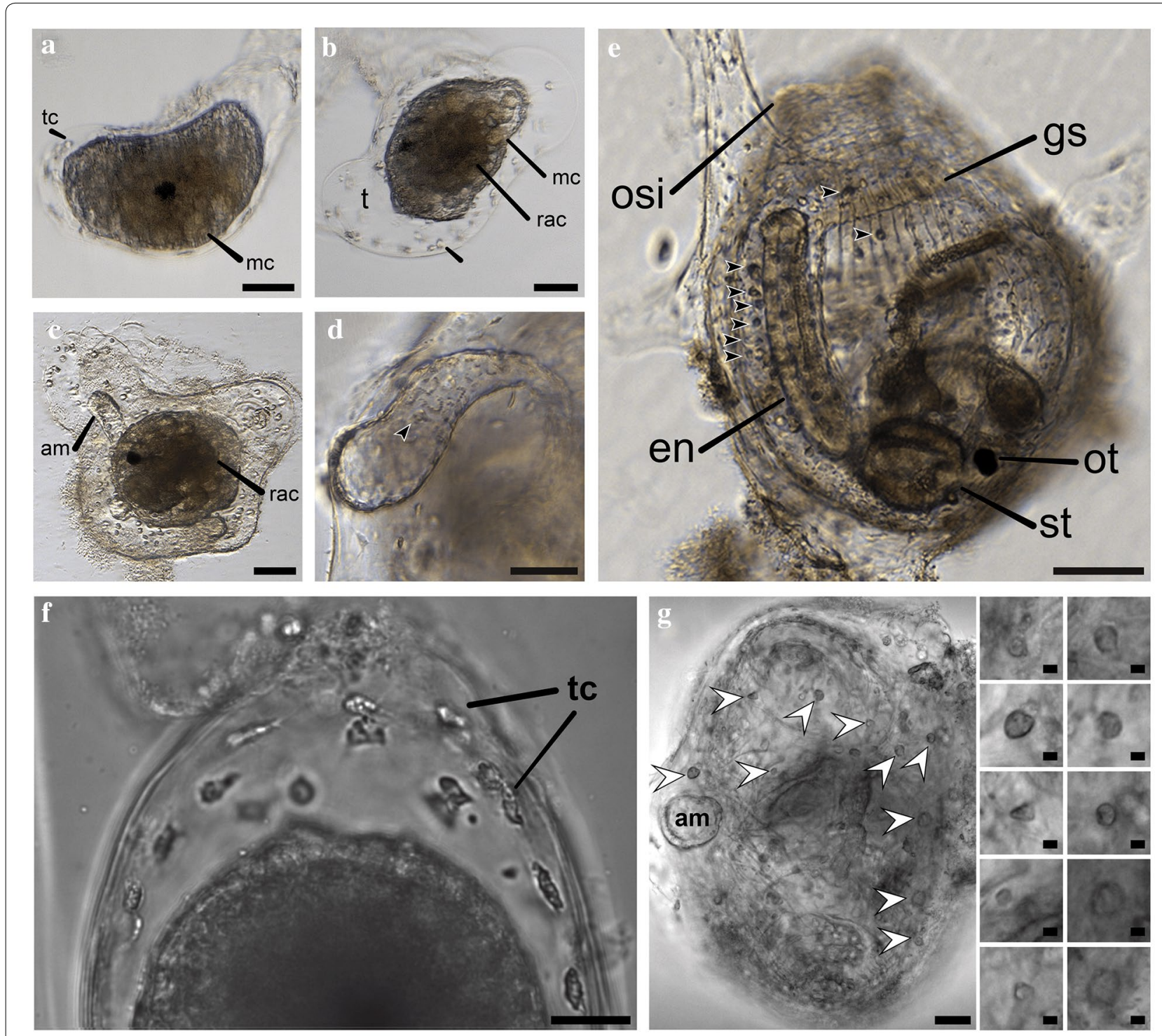

Fig. 6 Motile cells become apparent during metamorphosis. a Early stage of metamorphosis, $17 \mathrm{~h} 30 \mathrm{~m}$ post-fertilization, shows the earliest motile cells: ameboid tunic cells and globular mesenchyme cells (pf); $\mathbf{b}$ mid-metamorphosis stage, $20 \mathrm{~h} 30 \mathrm{~m}$ pf, reveals the rudiment of the alimentary (rac) canal in differentiation; c late metamorphosis stage, $25 \mathrm{~h} 15 \mathrm{~m} \mathrm{pf}$, exhibits the presence of extended ampullae; d detail of a post-metamorphic ampulla, $48 \mathrm{~h} \mathrm{pf}$, reveals new circulatory cell types in the lumen (arrowhead); e juvenile, $48 \mathrm{~h} \mathrm{pf}$, indicates the presence of pigmented circulating cells (arrowheads). $\mathbf{f}$ Detail of amoeboid tunic cells during metamorphic expansion of the tunic. $\mathbf{g}$ Detail of circulating cells (arrowheads and insets on the right) in a ventral view of a juvenile. Tunic cell (tc), globular mesenchyme cell (mc), tunic (t), otolith (ot), rudiment of the alimentary canal (rac), ampulla (am), oral siphon (osi), endostyle (en), gill slit epithelium (gs), stomach (st). Scale bars = $100 \mu \mathrm{m}$ in a-e; $50 \mu \mathrm{m}$ in $\mathbf{f} ; 25 \mu \mathrm{m}$ in $\mathbf{g}$ (left), $5 \mu \mathrm{m}$ in $\mathbf{g}$ (right) 
protrusions derived from the epidermis-very similar to colonial ascidian ampullae- began to extend radially and ventrally in four directions from the animal (Fig. 6b, c), and during the next 2-5 h, the ampullae reached full extension (Fig. 6c, d). Ampullae either extended on the underlying substrate or in the absence of a substrate they extended outwards or upwards, i.e., distally from the body. At this stage, the ampullae began to exhibit circulating cells in their lumen at the same time as waves of contractions of the ampullar epithelia were observed. Each wave lasted approximately $1 \mathrm{~min}$ (data not shown).

After 1 week of settlement, the four juvenile ampullae were resorbed, and the tunic of the juvenile continued to thicken. Simultaneously, the siphons opened and the cilia in the gill slits of the branchial basket started to beat. Shortly after these events, the first heartbeats were observed. Hemocytes with heterogeneous morphologies and sizes were already present at this stage (Fig. 6e, g). Thus, by the first week after fertilization, the circulatory system was clearly functional.

\section{Discussion \\ Circulating putative stem cells (CPSCs) in solitary and colonial styelid ascidians}

In the solitary styelid Styela plicata, we observed two cell types that show a small size, round shape, and large nucleus: hemoblasts and lymphocyte-like cells. The slightly larger hemoblast $(\sim 6 \mu \mathrm{m})$ contains one or several nucleoli in its nucleus and represents the undifferentiated hemocyte type or CPSC; whereas, the lymphocytelike cell is slightly smaller $(\sim 3-5 \mu \mathrm{m})$, lacks nucleoli and has been implicated in inflammatory reactions $[25,47]$. In contrast, in the Botryllus literature the term 'lymphocyte-like cell' or simply 'lymphocyte' has been misused to refer to the hemoblast or the undifferentiated circulating hemocyte type [48]. The two terms to describe a single cell type in Botryllus, as well as the presence of two morphologically similar cell types in Styela, have generated some confusion in the nomenclature of progenitor hemocyte types in ascidians. Although further comparative and functional studies of the lymphocyte-like cells and hemoblasts in different species of Styela are needed to unequivocally distinguish these two hemocyte types, microscopic observations have raised the possibilities that these cells correspond to immature or transitional stages of the same cell type $[5,49,50]$, where hemoblasts may be the general precursor stem cells giving rise to lymphocyte-like cells and other hemocytes (unpublished observations from our labs), or alternatively that these cells represent different cell type progenitors, i.e., immunologically active undifferentiated cells and hematopoietic cells, respectively $[5,49,51]$. Likely biased by an equivocal distinction between lymphocyte-like cells and hemoblasts, Sawada et al. [52] reported the presence of one single small hemocyte type (4-6 $\mu \mathrm{m}$ in diameter) that represented $\sim 14 \%$ of all cell types in the hemolymph. This size range and proportion of small cells in the hemolymph of Styela clava are very similar to the size range and proportion of small hemocytes we report here for $S$. plicata $(3-6 \mu \mathrm{m}$ in diameter and $\sim 16.7 \%)$ and likely correspond to both small cell types combined, i.e., lymphocyte-like cells + hemoblasts. Thus, it is very likely that $S$. clava also contains both types of small cells present in $S$. plicata. In summary, we highlight the occurrence of distinct circulating cell types resembling undifferentiated cells in S. plicata, and argue for their occurrence in other solitary Styela species.

The existence of CPSCs in the hemolymph of S. plicata is further supported by the presence of a low-granularity ALDH + population of hemolymph isolated by flow cytometry. But what is the frequency of cells with low granularity and high ALDH expression in a solitary ascidian when compared to a colonial ascidian? In the colonial B. schlosseri, it has been estimated that 1 out of 500-1000 hemocytes corresponds to circulating stem cells that are able to replicate and differentiate inducing genetic chimerism in parabiosed partners [12]. After ALDH enrichment, 1 out of 25-50 high ALDH expressing cells $(\mathrm{ALDH}+)$ shows stem cell capabilities, i.e., selfrenewal and multilineage potential. Thus, the ALDH assay increases 10-20-fold the frequency of putative stem cells in a population of ALDH + cells when compared to a non-sorted control population of hemocytes. In contrast, the ALDH assays in this study generated a fourfold enrichment of ALDH + hemocytes in S. plicata; in other words, ALDH + cells represent $7.36 \pm 6.8 \%$ of all S. plicata hemocytes. A lower enrichment of ALDH + cells observed in our assays may reflect a lower occurrence of CPSCs in S. plicata than in B. schlosseri. Prospective isolation of ALDH + cell populations, as well as non-sorted hemocyte populations, is necessary to better estimate the fractions that correspond to CPSCs in the S. plicata hemolymph. In sharp contrast, we estimated in direct visual cell counts that $\sim 17 \%$ of all hemocytes presented morphological features of CPSCs in S. plicata; whereas, only $\sim 4 \%$ of all hemocytes correspond to hemoblasts in B. schlosseri and Polyandrocarpa misakiensis [23, 53]. The difference between the percentages of ALDH + cells and hemocytes with a CPSC morphology between the visual counts and the flow cytometry counts in S. plicata may be due to the fact that both hemoblasts and lymphocyte-like cells were counted together under the category of small cells because in many cases we could not tell them apart. It remains to be determined what fraction of the small cells corresponds exclusively to CPSCs. 
When we compare all the different hemocytes that have been identified in Styelidae, we find that circulating cell types have been gained and lost in the different styelid species [5, 54], but overall we observe the occurrence of more kinds of hemocytes in colonial styelids than in their solitary counterparts. Nonetheless, S. plicata contains two hemocytes (i.e., hemoblasts and lymphocyte-like cells) that resemble CPSC morphology, while all colonial styelid species-including Botryllus spp., Botrylloides spp., P. misakiensis, and Symplegma brakenhielmi-studied to date only show the occurrence of the hemoblast cell type. Thus far, we have not found any evidence for the occurrence of a Styela-like lymphocyte lineage (see above) in any colonial styelid species [23, 28, 53, 54]. In general, the presence of more kinds of hemocytes in colonial ascidians implies that these cells have specialized in relation to biological processes of a colonial life history, such as allorecognition, colony homeostasis, colony-wide processes development, or asexual reproduction.

\section{The Styela plicata intestinal submucosa as a putative stem cell niche}

The intestinal submucosa cell types and general organization in S. plicata show resemblance to previously described stem cell "niches" in other animals $[1,55,56]$. In adult fish, for example, a heterogeneous population of mature hematopoietic cells and their precursors are observed among fat and stromal elements in compartments situated between the renal tubes of the kidney [55]. Both by histology and ultrastructure, precursor cells in the hematopoietic compartments of fish $[55,57]$ were very similar to the undifferentiated cell progenitors we observed in the aggregates in the intestinal submucosa of S. plicata.

Our data show the occurrence of a population of undifferentiated cells or putative hemoblasts confined within an extracellular matrix in the intestinal submucosa. As observed, in many animal species, such as crustaceans, mammals, and Drosophila [58-60]. The fate of CPSCs is regulated by a particular microenvironment, known as a "niche". Studies have revealed that the niche corresponds to a specific localization of the body where stem cells reside [61]. The niche functions as a physical anchor for stem cells, apart from generating extrinsic or intrinsic factors that control their number and fate [62]. In many types of niches, the basement membrane and extracellular matrix of niche epithelial cells provide mechanical or signaling anchoring for stem cells [62, 63]. In the S. plicata gut, we observed several aggregates of undifferentiated cells within the extracellular matrix of the submucosa region in close proximity to the basement membranes of either the mucosa or serosa epithelial cells. Such an organization of hemoblast aggregates in the intestinal niche suggests the possible presence of paracrine signaling from the basement membranes of the intestine and/or autocrine signaling from the hemoblasts themselves.

Cellular aggregates in the S. plicata intestinal submucosa show similarities to putative stem cell niches that have been documented for other ascidians, including Styela clava [49] and Ciona [64, 65]. Ermak [49, 66] observed in various styelids that stem cell niches are either organized in nodules or appear diffused. In S. clava, he localized hematopoietic nodules along the transverse and longitudinal vessels of the pharynx, on the body wall endocarps and around the gut and gonads $[49,67]$. The pharyngeal nodules of $S$. clava also contained clusters of hemoblasts surrounded by various cell types at different stages of differentiation, as we described for the intestinal submucosa of S. plicata in this study; however, hemocyte differentiation follows a more organized, sequential, and concentric arrangement of hemocyte differentiation in the pharyngeal nodules of S. clava [50] in sharp contrast to the less organized arrangement observed in cell aggregates of the intestinal submucosa of $S$. plicata. The different morphological arrangements of these putative niches in S. clava and $S$. plicata suggest a clearly distinct cellular and developmental nature of these tissues. In contrast in colonial styelidsspecifically in Botryllus and Botrylloides-several potential hematopoietic nodules and stem cell niche locations have been proposed, including: (i) in the anterior ventral region of the endostyle [68], (ii) in ventrally located cellular aggregates known as cell islands [69], (iii) in cellular aggregates lining within the vessels of the circulatory system of colonies [49, 70], and (iv) in compact cell clusters of the gonads [71]. Altogether, these results suggest the presence of multiple adult niches in the different styelid species, which may be specialized to contain different progenitors.

To test whether putative hemoblasts in the intestinal submucosa of S. plicata showed a molecular profile of stem cells, we analyzed molecular markers of stemness (PIWI) and proliferation (pHH3). PIWI belongs to the PIWI/Argonaute superfamily of RNA interference effector proteins, and is essential for self-renewal and maintenance of germline and somatic stem cells $[15,20,72$, 73]. As expected, we observed that PIWI + cells in the ovary (Additional file 3: Figure S2), but were also well represented in the submucosa of the S. plicata intestine (approx. 17\% of all cell types), from which only a third showed pHH3 expression (approx. 6\%). Although most pHH3 + cells were small and resembled hemoblast-like cells, PIWI + cells varied significantly in size and shape. Studies of PIWI expression in the Drosophila melanogaster ovary have shown that PIWI is expressed not only in germline stem cells (GSCs) to maintain undifferentiation, but also in two other differentiated somatic 
cell types of the ovary: (a) the associated somatic cap cells that also contribute to the maintenance of undifferentiation in GSCs, and (b) in the escort cells that actually promote GSCs differentiation [74]. Therefore, PIWI expression in multiple differentiated cell types of the $S$. plicata intestinal submucosa is not entirely unexpected, and it is tantalizing to consider that these cells have a role in the regulation of hemoblast maintenance or differentiation, as shown above for PIWI-expressing somatic cells in the Drosophila ovary. As an alternative, the commercially available antibody used in this study may be recognizing two distinct PIWI isoforms that may be expressed in different cell types [15], including undifferentiated hemoblasts and other differentiated somatic cells of the $S$. plicata submucosa (Additional file 3: Figure S2). At present, we believe that the true population of hemoblasts in the submucosa consists of a subset of proliferating small cells that simultaneously express PIWI $(<5 \%$ of cells present in the submucosa). To reliably identify and calculate the occurrence of hemoblast populations in the S. plicata submucosa, future studies should clone a handful of stem cell marker genes in S. plicata to test for co-expression of these markers in single progenitor and precursor cells of the submucosa.

Are hemoblasts in the submucosa able to transmigrate through the serosa epithelia to become CPSCs in the hemocoel in S. plicata? Although the undifferentiated cells in the intestine resemble hemoblasts in the hemolymph in their morphology [25] (i.e., a high nucleus/cytoplasm ratio, presence of nucleoli within the large nucleus, and presence of small electron-dense granules with few or no organelles in the cytoplasm), our data do not show a developmental or functional relationship between these two populations. Some of us are currently testing the potential of progenitor cells in the submucosa, including the hemoblasts, as a source of CPSCs in the hemolymph by cell culture, transplant, and tracking analyses.

\section{Ontogenetic origin of circulatory cells occurs at metamorphosis}

To explore the ontogenetic origin of adult circulatory putative stem cells (CPSCs) in Styela plicata, we characterized cell types and observed cell behavior during metamorphosis and early juvenile development. In vertebrates, circulatory cells of the blood originate in four sequential waves, in which the distinct hematopoietic cell lineages arise temporally apart from each other. The development of embryonic (i) macrophages and (ii) erythrocytes represent the first two waves during the so called "primitive" hematopoiesis, whereas the development of (iii) erythro-myeloid progenitors (EMPs) and (iv) multipotent hematopoietic stem cells (HSCs) represent the last two waves of the "definitive" or adult hematopoiesis in vertebrates [75]. In this first attempt to characterize the earliest appearance of circulatory cells (i.e., hemocytes) in S. plicata, we could observe the occurrence of at least three sequential waves. We hypothesize that the first two waves correspond to the appearance of the (i) amoeboid cells and (ii) globular mesenchyme cells during the early events of metamorphosis, and which may be considered analogous to the "primitive" hematopoiesis of vertebrates as these mesenchymal and freely moving hemocytes appeared only during metamorphosis. Although we could not identify the origin or molecularly characterize any of these early motile cell types in S. plicata, we suspect that the globular mesenchyme cells correspond to apoptotic muscle cells that dissociate during tail resorption previously observed in other metamorphosing solitary ascidians $[76,77]$. The following sequential waves of hematopoiesis only occurred a week later ( 1 week after settlement) and gave rise to other various hemocytes, including hemoblast precursors or CPSCs of juveniles and adults. These observations only represent the beginning of more research that is necessary to reliably elucidate the developmental origin of each adult hematopoietic lineage.

In contrast to the characteristic waves of hemocytes and circulatory cells that arise during ontogeny, adult development rarely generates any new hemocyte types [78]. Although we did not observe a change in the number of circulating cell populations in S. plicata adults of different sizes, we observed increased variation of granularity in hemocytes of larger animals consistently. Recent studies in human cell lines have shown a relationship between granularity in cells (estimated by SSC) and cellular senescence $[79,80]$, which results from the accumulation of more lysosomes and other autophagic vesicles [81]. According to Yamaguchi [82], S. plicata individuals of approximately $40 \mathrm{~mm}$ are already sexually mature, and can be between 2 months (summer) or 5 months (winter) old. Because ascidians in our study ranged between 10 and $45 \mathrm{~mm}$, we can estimate the age of the ascidians used here to be between 1 and 5 months old [82]. Although we favor the hypothesis that more variation in granularity in hemocytes of larger S. plicata individuals is a result of a senescent phenotype, we cannot exclude the possibility that as animals grow, the diversity of granulated hemocytes increases due to physiological or developmental demands. It may be interesting to compare the ontogenetic diversification of hemocytes, as well as hemocyte senescence in solitary and colonial ascidians where demands of particular types of hemocytes change during the life cycle. 


\section{Implications of CPSCs for the evolution of coloniality in styelids}

The presence of CPSCs in Styelidae raises questions about their developmental dynamics, and possible roles in developmental processes. Whereas CPSCs in colonial styelids, including Botryllus and Botrylloides, have been studied for their involvement in asexual reproduction and regeneration, the presence of CPSCs with hemoblast features (i.e., lack of granules, round morphology with prominent nucleus, and high ALDH activity) in the solitary Styela is not at all surprising because of its well-documented siphon and neural complex regeneration abilities $[27,51,67]$. Thus, the presence of CPSCs in all solitary and colonial ascidians studied so far supports the hypothesis that the styelid ancestor likely contained CPSCs and mechanisms to regulate CPSC functional dynamics. We currently have evidence for the evolution of at least two independent events of coloniality in the Styelidae [21], suggesting a degree of evolvability in the developmental program of adult stem cell lineages. Key modifications in adult stem cell characteristics may have allowed the developmental processes underlying coloniality to evolve as a result of novel selective interplays between cellular lineages. Further insights into this evolutionary transition will come from comparisons among species of interest in Styelidae.

\section{Conclusion}

We report the presence of morphologically undifferentiated cell types with high aldehyde dehydrogenase activity in the hemolymph of the solitary ascidian Styela plicata, which we refer to as circulating putative stem cells (CPSCs). In adult individuals, we find mitotic undifferentiated cell aggregates in the intestinal submucosa that resemble a hematopoietic niche. The earliest appearance of hemocytes during development occurs during metamorphosis of the larva, at a time when circulatory mesenchyme cells show distinct morphotypes from juvenile or adult hemocyte populations. We highlight the importance of our findings for future investigations about the direct involvement of CPSCs in regeneration of solitary ascidians, and about the consequences of the presence of CPSCs in styelid ascidians for the evolution of coloniality.

\section{Supplementary information}

Supplementary information accompanies this paper at https://doi. org/10.1186/s13227-019-0144-3.

Additional file 1: Figure S1. ALDEFLUOR ${ }^{\mathrm{TM}}$ analyses optimization procedures for excluding doublets and debris, and to evaluate autofluorescence of Styela plicata hemocytes. (A) Gating strategy used to exclude doublets and debris from the analysis. The scatterplots present all data points available. The gate 'single cells' (Red) was selected based on area and aspect ratio features (width in relation to total area) and using direct observations of single celled images for further analysis. (B) Scatterplot of the 'single cells' gate showing one possible gating strategy to separate 'small' and 'large cells'. (C) Histograms showing the normal frequencies of cells at different intensities of fluorescence in the green channel (Ch02) of the 'small cells' and 'large cells' gates in the blank control above (i.e., no $B A A A)$, and in cells treated with BAAA (i.e., ALDEFLUOR ${ }^{T M}$ ); the dotted line indicates the recommended threshold of intensity to consider a positive result. (D) Randomly selected brightfield and fluorescent images of cells of the 'small cells' and 'large cells' gates of the blank control show complete absence of autofluorescence. (C, D) demonstrate a clear absence of autofluorescence in S. plicata hemocytes.

Additional file 2: Table S1. Gate polygon coordinates for Styela plicata hemocyte BAAA assay.

Additional file 3: Figure S2. Evaluation of PIWI antibody cross-reactivity. (A) Alignment of PIWI proteins in the fly Drosophila melanogaster (Dromel), the annelid Pristina leidyi (Prilei), and ascidians: Styela plicata (Stypli), Botrylloides leachi (Botlea), Botryllus primigenus (Botpri), Botryllus schlosseri (Botsch), and Ciona robusta (Ciorob). Conserved PAZ and PIWI domains are shown below the Drosophila melanogaster PIWI sequence (Dromel_piwi_varA). The sequence region used to generate the epitope for the commercially available antibody used in this study is also shown overlapping the PAZ domain (582-689 aa). Color codes used to represent sequence conservation (Blosum62 score matrix for similarities): white $(<60 \%)$, light gray (60-79\%), dark gray (80-99\%), and black (100\%). Sequence similarities (Blosum62) at the region of the epitopes between $S$. plicata and D. melanogaster PIWI orthologs are above 70\% (i.e., 70.1\% Stypli_piwi_b vs. Dromel_varA and Dromel_varB; and 72.5\% Stypli_piwi_a vs. Dromel_varA and Dromel_varB). (B-D) Positive control shows PIWI + cells (arrows) surrounding three oocytes of different stages (asterisks); DAPI in (B), 1ary anti-PIWI + 2ary Alexa488 in (C), and overlay in (D); Note: Because PIWI is expressed in the germ cells of ovaries in all ascidian species studied to date, we used positive cell labelings in presumptive germ cells in $\mathrm{S}$. plicata ovaries as indicative of PIWI expression. $(\mathrm{F}-\mathrm{H})$ Blank control (i.e., no 1 ary anti-PIWI antibody) of S. plicata ovaries shows absence of labeling in germ cells around the oocytes; DAPI in (B), only 2ary Alexa488 in (C), and overlay in (D).

\section{Acknowledgements}

The authors thank Stefania Gutierrez, Luiza Saad, Taynan Portal and David Soares for their valuable comments and help. Thanks to Prof. Regina P. Markus for availability of the FlowSight cytometer (grant number FAPESP Temático Multiusuário 2014/20809-1). Many thanks to the CEBIMar staff for support in the field, and Sandra Muxel for technical support with flow cytometry. We also thank José Marián and Fernando Carbayo for their valuable comments during histological procedures. The authors are also indebted to the Rudolph Barth Electron Microscopy Platform of the Oswaldo Cruz Institute/Fiocruz.

\section{Authors' contributions}

$J$ J, FDB, ISA, SA, LSH, and CMB conceived and designed the study. JJ, and ISA performed the experiments and analyses. CMB, FDB, ST, SA, and LSH. helped with the interpretation of the data. JJ, FDB, ISA, LSH, and CMB wrote the manuscript. All authors read and approved the final manuscript.

\section{Funding}

This work was supported by FAPESP 2016/07607-6 Grant to J.J., FAPESP JP 2015/50164-5 and BPE 2019/06927-5 Grants to F.D.B., FAPESP 2018/05923-3 and 2015/14052-8 to L.S.H., ANR-14-CE02-0019-01 and PICS-CNRS Grants to S.T., FAPERJ E-26/111.705/2011, E-26/201.434/2014, E-26/010.001823/2015, E-26/202.762/2017, and CNPq Grants 471250/2011-2, c to S.A., FAPERJ E-26/203.021/2018 Grant to C.M.B.

Availability of data and materials

Data sharing not applicable to this article as no datasets were generated or analyzed during the current study 
Ethics approval and consent to participate

Not applicable.

\section{Consent for publication}

Not applicable.

\section{Competing interests}

The authors declare no competing interests as defined by Nature Research, or other interests that might be perceived to influence the results and/or discussion reported in this paper.

\begin{abstract}
Author details
${ }^{1}$ Departamento de Zoologia, Instituto de Biociências, Universidade de São Paulo, Rua do Matão, Trav. 14, São Paulo, SP 101 05508-090, Brazil. ${ }^{2}$ Centro de Biologia Marinha (CEBIMar), Universidade de São Paulo, São Paulo, Brazil. ${ }^{3}$ Laboratório de Neurobiologia Comparativa e do Desenvolvimento, Pós-Graduação em Ciências Biológicas-Fisiologia, Instituto de Biofísica Carlos Chagas Filho, Universidade Federal do Rio de Janeiro, UFRJ, Rio de Janeiro, RJ, Brazil. ${ }^{4}$ Pós-Graduação em Ciências Morfológicas, Instituto de Ciências Biomédicas, Universidade Federal do Rio de Janeiro, UFRJ, Rio de Janeiro, RJ, Brazil. ${ }^{5}$ CNRS, Laboratoire de Biologie du Développement de Villefranche-sur-mer (LBDV), Sorbonne Universités, 06230 Paris, France. ${ }^{6}$ Laboratório Integrado de Morfologia, Núcleo em Ecologia e Desenvolvimento Sócio Ambiental de Macaé, NUPEM, Universidade Federal do Rio de Janeiro, UFRJ, Macae, RJ, Brazil.

${ }^{7}$ Instituto Nacional de Ciência e Tecnologia em Estudos Interdisciplinares e Transdisciplinares em Ecologia e Evolução (IN-TREE), Salvador, BA, Brazil.
\end{abstract}

\section{Received: 25 June 2019 Accepted: 2 November 2019}

Published online: 25 November 2019

\section{References}

1. Hartenstein V. Blood cells and blood cell development in the animal kingdom. Annu Rev Cell Dev Biol. 2006;22:677-712. https://doi.org/10.1146/ annurev.cellbio.22.010605.093317.

2. Glynn LE. Living blood cells and their ultrastructure. Immunology. 1974;27:745.

3. Muñoz-Chápuli R, Carmona R, Guadix JA, Macías D, Pérez-Pomares $J M$. The origin of the endothelial cells: an evo-devo approach for the invertebrate/vertebrate transition of the circulating system. Evol. Dev. 2005:7:351-8. https://doi.org/10.1111/j.1525-142X.2005.05040.x.

4. Lebestky T, Chang T, Hartenstein V, Banerjee U. Specification of Drosophila hematopoietic lineage by conserved transcription factors. Science. 2000;288:146-9.

5. Wright RK. Urochordates. In: Invertebrate blood cells. London: Academic Press; 1981; p. 565-625.

6. Stolfi S, Brown FD. In: Wanninger, A. (Ed.), Tunicata. Evolutionary developmental biology invertebrates, Berlin. 2015.

7. Oka H, Watanabe H. Vascular Budding, a new type of budding in Botryllus. Biol Bull. 1957:112:225-40.

8. Oka H, Watanabe H. Vascular budding in Botrylloides. Biol Bull. 1959:117:340-6.

9. Sabbadin A. Osservazioni sullo sviluppo, l'accrescimento e la riproduzione di Botryllus schlosseri (Pallas), in condizioni di laboratorio. Bolletino di Zool. 1955;22:243-63.

10. Sabbadin A, Zaniolo G. Sexual differentiation and germ-cell transfer in the colonial ascidian Botryllus schlosseri. J Exp Zool. 1979;207:289-304.

11. Brown FD, Swalla BJ. Evolution and development of budding by stem cells: ascidian coloniality as a case study. Dev Biol. 2012;369:151-62. https ://doi.org/10.1016/j.ydbio.2012.05.038.

12. Laird DJ, De Tomaso AW, Weissman IL. Stem cells are units of natural selection in a colonial ascidian. Cell. 2005;123:1351-60. https://doi. org/10.1016/j.cell.2005.10.026.

13. Rinkevich Y, Rosner A, Rabinowitz C, Lapidot Z, Moiseeva E, Rinkevich B. PIWI positive cells that line the vasculature epithelium, underlie whole body regeneration in a basal chordate. Dev Biol. 2010;345:94-104. https ://doi.org/10.1016/j.ydbio.2010.05.500.

14. Brown FD, Keeling EL, Le AD, Swalla BJ. Whole body regeneration in a colonial ascidian, Botrylloides violaceus. J Exp Zool Part B Mol Dev Evol. 2009;312:885-900. https://doi.org/10.1002/jez.b.21303.
15. Brown FD, Tiozzo S, Roux MM, Ishizuka K, Swalla BJ, De Tomaso AW. Early lineage specification of long-lived germline precursors in the colonial ascidian Botryllus schlosseri. Development. 2009;136:3485-94. https://doi.org/10.1242/dev.037754.

16. Cima F, Perin A, Burighel P, Ballarin L. Morpho-functional characterization of haemocytes of the compound ascidian Botrylloides leachi (Tunicata, Ascidiacea). Acta Zool. 2001;82:261-74. https://doi.org/10.10 46/j.1463-6395.2001.00087.x.

17. Freeman $\mathrm{G}$. The role of blood cells in the process of asexual reproduction in the tunicate Perophora viridis. J Exp Zool. 1964;156:157-83. https ://doi.org/10.1002/jez.1401560204.

18. Manni L, Zaniolo G, Cima F, Burighel P, Ballarin L. Botryllus schlosseri: a model ascidian for the study of asexual reproduction. Dev Dyn. 2007;236:335-52. https://doi.org/10.1002/dvdy.21037.

19. Sabbadin A, Zaniolo G, Majone F. Determination of polarity and bilateral asymmetry in palleal and vascular buds of the ascidian Botryllus schlosseri. Dev Biol. 1975;46:79-87. https://doi.org/10.1016/00121606(75)90088-3.

20. Kawamura K, Sunanaga T. Hemoblasts in colonial tunicates: are they stem cells or tissue-restricted progenitor cells? Dev Growth Differ. 2010;52:69-76. https://doi.org/10.1111/j.1440-169X.2009.01142.X.

21. Alié A, Hiebert LS, Simion P, Scelzo M, Prünster MM, Lotito S, Delsuc F, Douzery EJP, Dantec C, Lemaire P, Darras S, Kawamura K, Brown FD, Tiozzo S. Convergent acquisition of nonembryonic development in styelid ascidians. Mol Biol Evol. 2018;35(7):1728-43.

22. De Leo G. Ascidian hemocytes and their involvement in defence reactions. Bolletino di Zool. 1992;59:195-214. https://doi. org/10.1080/11250009209386669.

23. Ballarin L, Cima F. Cytochemical properties of Botryllus schlosseri haemocytes: indications for morpho-functional characterisation. Eur J Histochem. 2005:49(3):255-64.

24. Blanchoud S, Zondag L, Lamare MD, Wilson MJ. Hematological analysis of the ascidian Botrylloides leachii (Savigny, 1816) during whole-body regeneration. The Biological Bulletin. 2017;232(3):143-57.

25. De Barros CM, De Carvalho DR, De Andrade LR, Pavão MSG, Allodi S. Nitric oxide production by hemocytes of the ascidian Styela plicata. Cell Tissue Res. 2009;338:117-28. https://doi.org/10.1007/s0044 1-009-0851-5.

26. Radford JL, Hutchinson AE, Burandt M, Raftos DA. A hemocyte classification scheme for the tunicate Styela plicata. Acta Zool. 1998;79:344-50. https://doi.org/10.1111/j.1463-6395.1998.tb01284.x.

27. Medina BNSP, Abreu ISD, Cavalcante LA, Silva WAB, Fonseca RN, Allodi S, Barros CMD. 3-acetylpyridine-induced degeneration in the adult ascidian neural complex: reactive and regenerative changes in glia and blood cells. Dev Neurobiol. 2014. https://doi.org/10.1002/dneu.22255.

28. Ballarin L, Kawamura K. The hemocytes of Polyandrocarpa misakiensis: morphology and immune-related activities. Invertebr Surv J. 2009;6:154-61.

29. Extavour CG, Akam M. Mechanisms of germ cell specification across the metazoans: epigenesis and preformation. Development. 2003;130(24):5869-84.

30. Osawa Y, Miyamoto T, Ohno S, Ohno E. Morphological analysis of live undifferentiated cells derived from induced pluripotent stem cells. Stem Cells Dev. 2018;27(1):1-9. https://doi.org/10.1089/scd.2017.0112 Epub 2017 Dec 5.

31. Rosental B, Kowarsky M, Seita J, Corey DM, Ishizuka KJ, Palmeri KJ, Chen SY, Sinha R, Okamoto J, Mantalas G, Manni L, Raveh T, Clarke DN, Tsai JM Newman AM, Neff NF, Nolan GP, Quake SR, Weissman IL, Voskoboynik A Complex mammalian-like haematopoietic system found in a colonial chordate. Nature. 2018;564(7736):425-9. https://doi.org/10.1038/s4158 6-018-0783-x

32. Kassmer $\mathrm{SH}$, Rodriguez D, De Tomaso AW. Colonial ascidians as model organisms for the study of germ cells, fertility, whole body regeneration, vascular biology and aging. Curr Opin Genet Dev. 2016;39:101-6. https:// doi.org/10.1016/j.gde.2016.06.001.

33. Kawamura K, Fujiwara S. Transdifferentiation of pigmented multipotent epithelium during morphallactic development of budding tunicates. Int J Dev Biol. 1994;38:369-77.

34. Kawamura K, Fujiwara S. Cellular and molecular characterization of transdifferentiation in the process of morphallaxis of budding tunicates. Semin Cell Biol. 1995;6:117-26. 
35. Locke A, Carman M, Editors G, Barros RC, De Rocha RM, Pie. Human-mediated global dispersion of Styela plicata (Tunicata, Ascidiacea). Aquat Invas. 2009:4:45-57.

36. Rocha RM, Bonnet NYK, Baptista MS, Beltramin FS. Introduced and native Phlebobranch and Stolidobranch solitary ascidians (Tunicata: Ascidiacea) around Salvador, Bahia, Brazil. Zoology. 2012;29:39-53. https://doi. org/10.1590/S1984-46702012000100005.

37. Sardet C, McDougall A, Yasuo H, Chenevert J, Pruliere G, Dumollard R, Hudson C, Hebras C, Nguyen NL, Paix A. Embryological methods in ascidians: the Villefranche-sur-Mer protocols. Methods Mol Biol. 2011;770:365-400.

38. Fallon P, Gentry T. Mobilized peripheral blood SSCloALDHbr cells have the phenotypic and functional properties of primitive haematopoietic cells and their number correlates with engraftment following autologous transplantation. Br. J. 2003;122:99-108. https://doi.org/10.104 6/j.1365-2141.2003.04357.x.

39. Jones RJ, Barber JP, Vala MS, Collector MI, Kaufmann SH, Ludeman SM, Colvin OM, Hilton J. Assessment of aldehyde dehydrogenase in viable cells. Blood. 1995;85:2742-6.

40. Storms RW, Trujillo AP, Springer JB, Shah L, Colvin OM, Ludeman SM, Smith C. Isolation of primitive human hematopoietic progenitors on the basis of aldehyde dehydrogenase activity. Proc Natl Acad Sci USA. 1999;96:9118-23. https://doi.org/10.1073/pnas.96.16.9118.

41. Jones RJ, Collector MI, Barber JP, Vala MS, Fackler MJ, May WS, Griffin C, Hawkins L, Zehnbauer B, Hilton J, Colvin OM, Sharkis SJ. Characterization of mouse lymphohematopoietic stem cells lacking spleen colony-forming activity. Blood. 1996;88:487-91.

42. Gurr E. Biological staining methods. 8th ed. U.K.: Searle Diagnostics; 1973.

43. Humason GL. Animal tissue techniques. 3rd ed. Freeman: W. H; 1972.

44. Swalla BJ. Procurement and culture of ascidian embryos. In: Methods in cell biology. Academic Press. 2004; vol. 74, p. 115-141.

45. De Barros CM, Emrich LC, Mello ADA, Da Fonseca RN, Allodi S. Regulation of nitric-oxide production in hemocytes of the ascidian Phallusia nigra. Nitric Oxide Biol Chem. 2014;38:26-36. https://doi.org/10.1016/j. niox.2014.02.007.

46. De Barros CM, Andrade LR, Allodi S, Viskov C, Mourier PA, Cavalcante MCM, Straus AH, Takahashi HK, Pomin VH, Carvalho VF, Martins MA, Pavão MSG. The haemolymph of the ascidian Styela plicata (ChordataTunicata) contains heparin inside basophil-like cells and a unique sulfated galactoglucan in the plasma. J Biol Chem. 2007;282:1615-26. https://doi. org/10.1074/jbc.M604056200.

47. Raftos DA, Cooper EL. Proliferation of lymphocyte-like cells from the solitary tunicate, Styela clava, in response to allogeneic stimuli. J Exp Zool. 1991;260(3):391-400.

48. Cima F, Franchi N, Ballarin L. Origin and functions of tunicate hemocytes. In: The evolution of the immune system. London: Academic Press. 2016; p. 29-49.

49. ErmakTH. The hematogenic tissue of tunicates. In: Wright RK, Cooper EL (Ed.). The phylogeny of thymus and bone marrow-bursa cells. Amsterdam. 1976; p. 45-56.

50. Wright, RK, Ermak, TH. Cellular defense systems of the Protochordata. In Phylogeny and Ontogeny. Berlin: Springer; 1982;283-320.

51. George WC. The formation of new siphon openings in the tunicate, Styela plicata. J. Elisha Mitchell Sci Soc. 1937;53:87-91.

52. Sawada T, Zhang J, Cooper EL. Classification and characterization of hemocytes in Styela Clava. Biol Bull. 1993;184(1):87-96. https://doi. org/10.2307/1542382.

53. Hirose E, Shirae M, Saito Y. Ultrastructures and classification of circulating hemocytes in 9 botryllid ascidians (Chordata: Ascidiacea). Zool. Sci. 2003;20:647-56. https://doi.org/10.2108/zsj.20.647.

54. Gutierrez S, Brown FD. Vascular budding in Symplegma brakenhielmi and the evolution of coloniality in styelid ascidians. Dev Biol. 2017;423(2):152-69.

55. Bennett CM, Kanki JP, Rhodes J, Liu TX, Paw BH, Kieran MW, Langenau DM, Delahaye-Brown A, Zon LI, Fleming MD, Look AT. Myelopoiesis in the zebrafish, Danio rerio. Blood. 2001;98(3):643-51.

56. da Chaves Silva PG, Benton JL, Beltz BS, Allodi S. Adult neurogenesis: ultrastructure of a neurogenic niche and neurovascular relationships. PLoS ONE. 2012;7(6):39267. https://doi.org/10.1371/journal.pone.00392 67.
57. Lutnicka H, Bojarski B, Król T, Trybus W, Trybus E, Kopacz-Bednarska A, Witeska M, Pankiewicz L, Pawlak K. Hematological parameters and ultrastructure of hematopoietic tissues in common carp (Cyprinus carpio $\mathrm{L}$ ) exposed to sublethal concentration of pendimethalin. Folia Biologica. 2018;66(3):121-32.

58. Noonin C. Involvement of Serotonin in crayfish hematopoiesis. Dev Comp Immunol. 2018;86:189-95.

59. Zhang J, Supakorndej T, Krambs JR, Rao M, Abou-Ezzi G, Ye RY, Li S, Trinkaus K, Link DC. Bone marrow dendritic cells regulate hematopoietic stem/progenitor cell trafficking. J Clin Investig. 2019. https://doi. org/10.1172/jci124829.

60. Xu N, Wang SQ, Tan D, Gao Y, Lin G, Xi R. EGFR, Wingless and JAK/STAT signaling cooperatively maintain Drosophila intestinal stem cells. Dev Biol. 2011;354(1):31-43.

61. Adams GB, Scadden DT. The hematopoietic stem cell in its place. Nat Immunol. 2006;7:333-7. https://doi.org/10.1038/ni1331.

62. Li L, Xie T. STEM CELL NICHE: structure and function. Annu Rev Cell Dev Biol. 2005;21:605-31. https://doi.org/10.1146/annurev.cellbio.21.01270 4.131525

63. Chacón-Martínez CA, Koester J, Wickström SA. Signaling in the stem cell niche: regulating cell fate, function and plasticity. Development. 2018. https://doi.org/10.1242/dev.165399.

64. De Leo G, Parrinello N, Di Bella MA. Fine structure of blood system in Ciona intestinalis L. (Tunicata). Vessels and hemocytes in pharyngeal wall. Arch Biol (Bruxelles).1987:98:35-52.

65. Jeffery WR. Regeneration, stem cells, and aging in the Tunicate Ciona: insights from the oral siphon. Int Rev Cell Mol Biol. 2015;319:255-82. https ://doi.org/10.1016/bs.ircmb.2015.06.005

66. Ermak TH. An autoradiographic demonstration of blood cell renewal in Styela clava (Urochordata: Ascidiacea). Experientia. 1975;31:837-9.

67. Chaves-da-silva PG, de Abreu IS, Cavalcante LA, De Barros CM, Allodi S. Role of hemocytes in invertebrate adult neurogenesis and brain repair ISJ. 2015;12:142-54.

68. Voskoboynik A, Soen Y, Rinkevich Y, Rosner A, Ueno H, Reshef R, Ishizuka KJ, Palmeri KJ, Moiseeva E, Rinkevich B, Weissman IL. identification of the endostyle as a stem cell niche in a colonial chordate. Cell Stem Cell. 2008;3:456-64. https://doi.org/10.1016/j.stem.2008.07.023.

69. Rinkevich Y, Voskoboynik A, Rosner A, Rabinowitz C, Paz G, Oren M, Douek J, Alfassi G, Moiseeva E, Ishizuka KJ, Palmeri KJ, Weissman IL, Rinkevich B. Repeated, long-term cycling of putative stem cells between niches in a basal chordate. Dev Cell. 2013;24:76-88. https://doi.org/10.1016/j.devce 1.2012 .11 .010

70. Kawamura K, Sugino YM. Cell adhesion in the process of asexual reproduction of tunicates. Microsc Res Tech. 1999;44:269-78. https:// doi.org/10.1002/(SICI)1097-0029(19990215)44:4\%3c269:AID-JEMT6 \%3e3.0.CO;2-K.

71. Sunanaga T, Satoh M, Kawamura K. The role of Nanos homologue in gametogenesis and blastogenesis with special reference to male germ cell formation in the colonial ascidian, Botryllus primigenus. Dev Biol. 2008;324:31-40. https://doi.org/10.1016/j.ydbio.2008.08.023.

72. Lin H. piRNAs in the germ line. Science. 2007;316:397. https://doi. org/10.1126/science.1137543.

73. Sunanaga T, Inubushi H, Kawamura K. PIWI-expressing hemoblasts serve as germline stem cells during postembryonic germ cell specification in colonial ascidian, Botryllus primigenus. Dev Growth Differ. 2010;52:603-14. https://doi.org/10.1111/j.1440-169X.2010.01196.X.

74. Ma X, Wang S, Do T, Song $X$, Inaba M, Nishimoto Y, Liu LP, Gao Y, Mao Y, Li H, McDowell W, Park J, Malanowski K, Peak A, Perera A, Li H, Gaudenz K, Haug J, Yamashita Y, Lin H, Ni JQ, Xie T. Piwi is required in multiple cell types to control germline stem cell lineage development in the Drosophila ovary. PLOS ONE. 2014;9(3):e90267. https://doi.org/10.1371/journ al.pone.0090267.

75. Stachura DL, Traver D. Cellular dissection of zebrafish hematopoiesis. Cell Biol. 2016. https://doi.org/10.1016/bs.mcb.2016.03.022.

76. Chambon JP, Soule J, Pomies P, Fort P, Sahuquet A, Alexandre D, Baghdiguian S. Tail regression in Ciona intestinalis (Prochordate) involves a Caspase-dependent apoptosis event associated with ERK activation. Development. 2002;129(13):3105-14.

77. Degnan BM, Souter D, Degnan SM, Long SC. Induction of metamorphosis with potassium ions requires development of competence and an 
anterior signalling centre in the ascidian Herdmania momus. Dev Genes Evol. 1997;206(6):370-6. https://doi.org/10.1007/s004270050066.

78. Gold KS, Brückner K. Drosophila as a model for the two myeloid blood cell systems in vertebrates. Exp Hematol. 2014;42(8):717-27. https://doi. org/10.1016/j.exphem.2014.06.002.

79. Lan YY, Heather JM, Eisenhaure T, Garris CS, Lieb D, Raychowdhury R, Hacohen N. Extranuclear DNA accumulates in aged cells and contributes to senescence and inflammation. Aging Cell. 2019;18(2):e12901. https:// doi.org/10.1111/acel.12901.

80. Kim YM, Byun HO, Jee BA, Cho H, Seo YH, Kim YS, Park MH, Chung HY, Woo HG, Yoon G. Implications of time-series gene expression profiles of replicative senescence. Aging Cell. 2013;12(4):622-34.

81. Ogrodnik M, Salmonowicz H, Gladyshev VN. Integrating cellular senescence with the concept of damage accumulation in aging: relevance for clearance of senescent cells. Aging Cell. 2018;18(1):e12841. https://doi. org/10.1111/acel.12841
82. Yamaguchi M. Growth and reproductive cycles of the marine fouling ascidians Ciona intestinalis, Styela plicata, Botrylloides violaceus, and Leptoclinum mitsukurii at Aburatsubo-Moroiso Inlet (Central Japan). Mar Biol. 1975;29(3):253-9.

83. Cammarata M, Arizza V, Parrinello N, Candore G, Caruso C. Phenoloxidasedependent cytotoxic mechanism in ascidian (Styela plicata) hemocytes active against erythrocytes and K562 tumor cells. Eur J Cell Biol. 1997;74(3):302-7.

\section{Publisher's Note}

Springer Nature remains neutral with regard to jurisdictional claims in published maps and institutional affiliations.
Ready to submit your research? Choose BMC and benefit from:

- fast, convenient online submission

- thorough peer review by experienced researchers in your field

- rapid publication on acceptance

- support for research data, including large and complex data types

- gold Open Access which fosters wider collaboration and increased citations

- maximum visibility for your research: over $100 \mathrm{M}$ website views per year

At BMC, research is always in progress.

Learn more biomedcentral.com/submissions 